\title{
Transport of branched tetraether lipids from the Tagus River basin to the coastal ocean of the Portuguese margin: consequences for the interpretation of the MBT'/CBT paleothermometer
}

\author{
C. Zell ${ }^{1}$, J.-H. Kim ${ }^{1}$, M. Balsinha ${ }^{2}$, D. Dorhout ${ }^{1}$, C. Fernandes ${ }^{2}$, M. Baas ${ }^{1}$, and J. S. Sinninghe Damsté ${ }^{1}$ \\ ${ }^{1}$ NIOZ Royal Netherlands Institute for Sea Research, Department of Marine Organic Biogeochemistry, P.O. Box 59, \\ 1790 AB Den Burg, the Netherlands \\ ${ }^{2}$ Marine Geology Division, Portuguese Hydrographic Institute, Lisbon, Portugal \\ Correspondence to: C. Zell (claudia.zell@erdw.ethz.ch) and J.-H. Kim (jung-hyun.kim@nioz.nl)
}

Received: 23 December 2013 - Published in Biogeosciences Discuss.: 7 March 2014

Revised: 27 June 2014 - Accepted: 4 September 2014 - Published: 14 October 2014

\begin{abstract}
Branched glycerol dialkyl glycerol tetraethers (brGDGTs), which are thought to be transported from soil to marine sediment by rivers, have been used to reconstruct the mean annual air temperature (MAAT) and soil $\mathrm{pH}$ of the drainage basin using the methylation index of branched tetraethers (MBT, recently refined as MBT') and cyclization index of branched tetraethers (CBT) from coastal marine sediment records. In this study, we trace the brGDGTs from source to sink in the Tagus River basin, the longest river system on the Iberian Peninsula, by determining their concentration and distribution in soils, river suspended particulate matter (SPM), riverbank sediments, marine SPM, and marine surface sediments. The concentrations of brGDGTs in river SPM were substantially higher and their distributions were different compared to those of the drainage basin soils. This indicates that brGDGTs are mainly produced in the river itself. In the marine environment, the brGDGT concentrations rapidly decreased with increasing distance from the Tagus estuary. At the same time, the brGDGT distributions in marine sediments also changed, indicating that marine in situ production also takes place. These results show that there are various problems that complicate the use of the MBT'/CBT for paleoreconstructions using coastal marine sediments in the vicinity of a river. However, if the majority of brGDGTs are produced in the river, it might be possible to reconstruct the environmental (temperature and $\mathrm{pH}$ ) conditions of the river water using appropriate aquatic calibrations, provided that marine core locations are chosen in such a way that the
\end{abstract}

brGDGTs in their sediments are predominantly derived from riverine in situ production.

\section{Introduction}

Branched glycerol dialkyl glycerol tetraethers (brGDGTs) are membrane-spanning lipids, most likely derived from heterotrophic (Pancost and Sinninghe Damsté, 2003; Oppermann et al., 2010; Weijers et al., 2010) bacteria that occur ubiquitously in peat (e.g., Weijers et al., 2006a) and soil (e.g., Weijers et al., 2007a). The major brGDGTs contain a variety of methyl groups (4-6) and may contain up to two cyclopentane moieties formed by internal cyclization (Sinninghe Damsté et al., 2000; Weijers et al., 2006a). Four of these methyl groups are present in mid-chain positions of the two $\mathrm{C}_{28}$ linear chains of the tetraether structure (Fig. 1), whilst the others are present at the C-5 and C-5' positions. Recently, De Jonge et al. (2013, 2014) identified four new isomers of the previously described pentamethylated and hexamethylated brGDGTs in a Siberian peat and suspended matter of the Yenisei River. These isomers are characterized by the presence of methyl groups at the C-6 and C-6' instead of the C-5 and C-5' positions. Concerning the biological origin of the brGDGTs, it has been found so far that brGDGT Ia (for structures, see Fig. 1) is produced by some species of Acidobacteria (Sinninghe Damsté et al., 2011). However, it remains unclear whether other bacteria are also able to produce brGDGTs. 
BrGDGTs

la

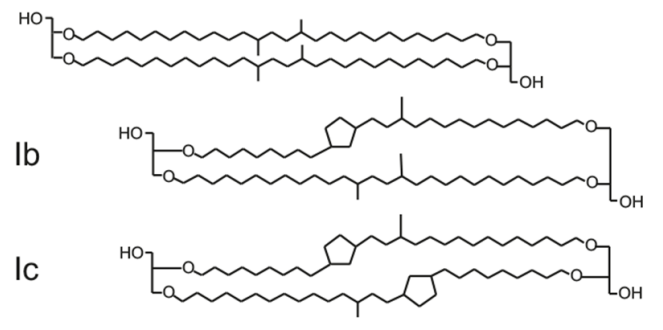

Ila

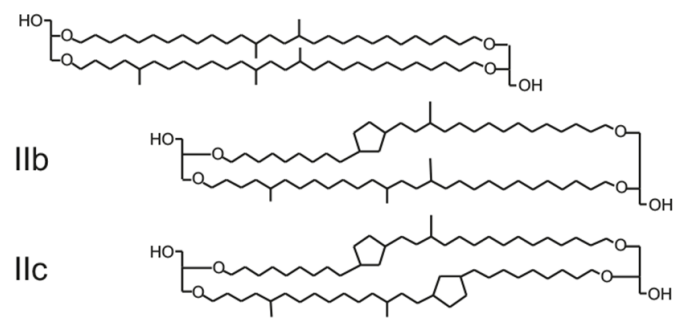

IIIa

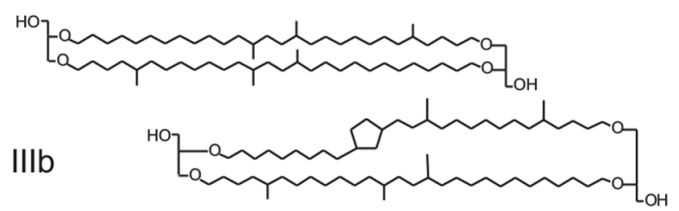

IIIC

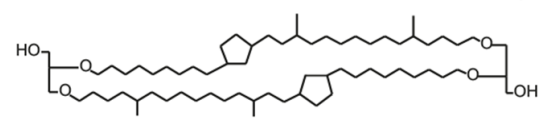

Crenarchaeol

IV

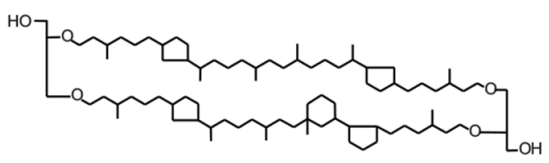

Figure 1. Chemical structure of brGDGTs (Ia-c, IIa-c, and IIIa-c) and crenarchaeol (IV).

The distribution of brGDGTs, as expressed by the degree of methylation (methylation index of branched tetraethers; MBT) and cyclization (cyclization index of branched tetraethers; CBT) of the brGDGTs, in soil correlates with mean annual air temperature (MAAT) and soil $\mathrm{pH}$ (Weijers et al., 2007a). The MBT/CBT proxy is one of the few quantitative temperature proxies that have been introduced for terrestrial environments. The MBT/CBT proxy has been used to reconstruct past MAAT changes in diverse settings: marine (e.g., Weijers et al., 2007b; Donders et al., 2009; Rueda et al., 2009; Bendle et al., 2010) and lacustrine (Tyler et al., 2010; Zink et al., 2010; Fawcett et al., 2011; Loomis et al., 2012; Niemann et al., 2012; D'Anjou et al., 2013) sediments, peat (Ballantyne et al., 2010), and loess deposits (Peterse et al., 2011a; Zech et al., 2012; Jia et al., 2013).

To reconstruct terrestrial climate changes using the MBT/CBT proxy, sediment cores taken in front of river outflows have been used (e.g., Weijers et al, 2007b). Initially, it was thought that brGDGTs were only produced in soils, washed into rivers by soil erosion, and transported to the marine environment where they are deposited in sediments. Consequently, it was thought that the MBT/CBT records of marine sediment cores would represent an integrated signal of the whole river drainage basin. An initial study that applied the MBT/CBT proxy in Congo deep-sea fan sediments (Weijers et al., 2007b) showed its potential to reconstruct changes of MAAT of the Congo basin over the last glaciation. However, subsequent studies have shown that in situ production in rivers (Yang et al., 2013; Zell et al., 2013a, b) and in the marine environment (Peterse et al., 2009; Zhu et al., 2011; Hu et al., 2012; Strong et al., 2012, Zell et al., submitted) may affect the original brGDGT signal of soil and, therefore, complicates the use of the MBT/CBT proxy. Depending on the river systems, it seems that the influence of in situ production can differ. In addition, other potential factors may hamper the application of the MBT/CBT proxy in coastal sediments. For example, an increased input of brGDGTs from a certain area of the drainage basin could obscure the representativeness of the entire river basin (Bendle et al., 2010; Strong et al., 2012). Therefore, it is of utmost importance to further investigate how different environmental conditions affect the application of the MBT/CBT proxy. Recently, the MBT was adjusted to the MBT', by excluding brGDGT IIIb and IIIc, because they occur less frequently in soil (Peterse et al., 2012). Hereafter, we will therefore use the term of the MBT'/CBT instead of the MBT/CBT.

The relative amount of brGDGTs to the isoprenoid GDGT, crenarchaeol, which is produced predominantly in the marine environment by Thaumarchaeota, may indicate a substantial input of soil organic matter to the ocean. This is expressed with the branched and isoprenoid tetraether (BIT) index (Hopmans et al., 2004), which is a helpful tool for deciding whether the MBT'/CBT proxy can be applied or not. Initially, a value of the BIT index of 1 was thought to indicate an environmental sample only containing soil organic matter, while a value of 0 was thought to reflect only aquatic organic matter. However, crenarchaeol is also produced in soils, which can lead to a value of the BIT index of $<1.0$ (Weijers et al., 2006b; Kim et al., 2010; Peterse et al., 2010; Yang et al., 2011). The BIT index is also influenced by the amount of crenarchaeol produced in the marine environment (e.g., Fietz et al., 2011; Smith et al., 2012; Wu et al., 2013) and by degradation processes (Huguet et al., 2008, 2009). This also shows that also for the BIT index further investigation is needed to understand how it can be used in river systems to trace the transport of soil organic matter and if it can be used to indicate if and where the MBT'/CBT can be used.

We performed a proxy validation study in the Tagus River system. Compared to the river systems which have been studied previously, like the Amazon (Bendle et al., 2010, Zell et al., 2013a, b), Congo (Weijers et al., 2007b), Yangtze (Zhu et al., 2011, Yang et al., 2013), and Yenisei (De Jonge et 

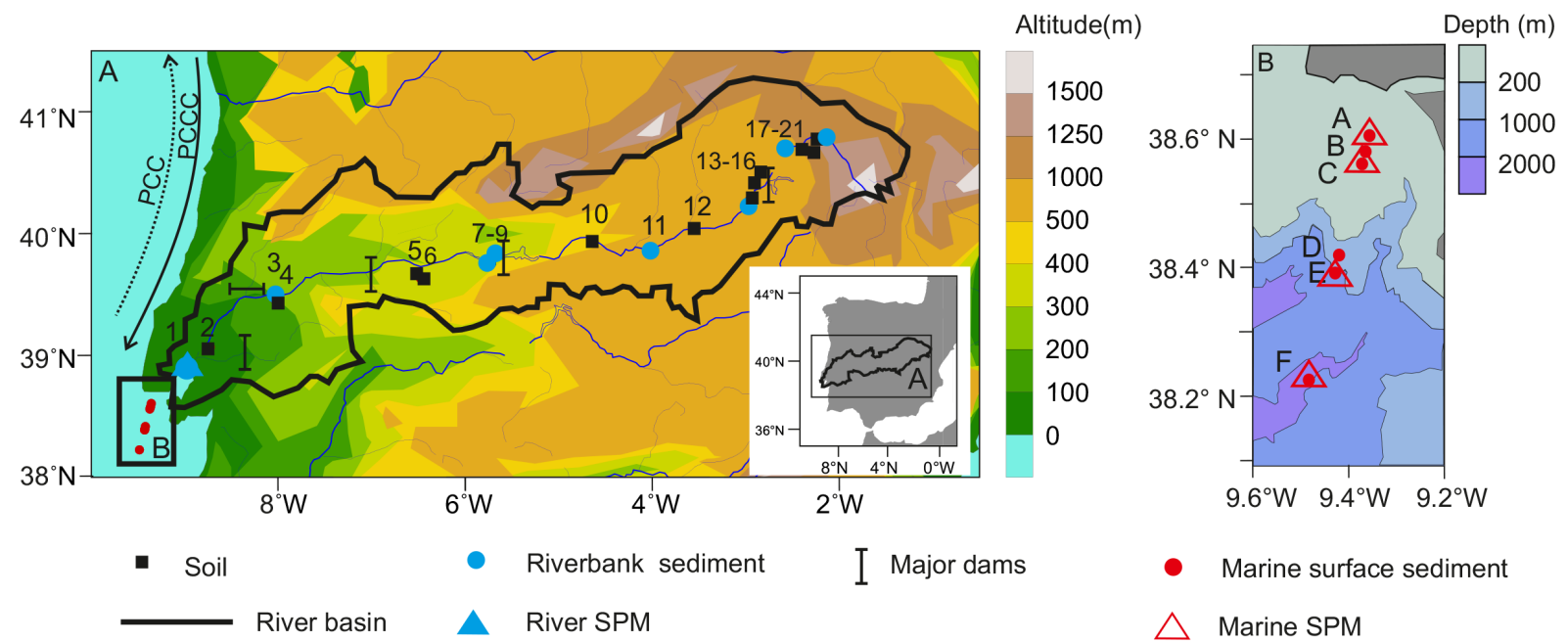

Figure 2. Overview of the study area with the sampling sites of soils, riverbank sediments, and river SPM (a) and detailed sampling locations of marine SPM and surface sediments (b). The major dams along the Tagus River are indicated in (a). PCC and PCCC indicate the surface currents, Portugal Coastal Current and Portugal Coastal Countercurrent, respectively.

al., 2014), the Tagus River system is smaller and located in a much drier climate zone. We traced the transport of brGDGTs from source to sink via rivers, identified the source of brGDGTs in marine sediments, and assessed the applicability of the MBT'/CBT proxy in the coastal ocean of the Portuguese margin. We analyzed brGDGTs and crenarchaeol in soils, in river suspended particulate matter (SPM) over a whole year, and in riverbank sediments collected in the Tagus River basin. In addition, marine SPM and surface sediments were analyzed along a transect from close to the Tagus estuary to the deep-sea Setúbal canyon. Core lipid (CL) and intact polar lipid (IPL)-derived GDGTs were analyzed, in order to distinguish recently produced (IPL-derived) GDGTs from older (CL) GDGTs.

\section{Study area}

The Tagus River is the longest river of the Iberian Peninsula, with a length of approximately $1000 \mathrm{~km}$ and a watershed of approximately $80,600 \mathrm{~km}^{2}$ (Fig. 2). Mean annual precipitation (MAP) in the catchment area varies between $<500 \mathrm{~mm} \mathrm{yr}^{-1}$ and around $900 \mathrm{~mm} \mathrm{yr}^{-1}$, and MAAT is from about $7{ }^{\circ} \mathrm{C}$ in the mountain areas to $17^{\circ} \mathrm{C}$ along the Atlantic coast (Atlas Nacional de España, 1993; Ninyerola et al., 2005). River water discharge shows large seasonal variations: the mean annual water discharge of the Tagus River is $360 \mathrm{~m}^{3} \mathrm{~s}^{-1}$, but ranges between 80 and $720 \mathrm{~m}^{3} \mathrm{~s}^{-1}$. Monthly average discharges can vary between 1 and $2200 \mathrm{~m}^{3} \mathrm{~s}^{-1}$ (Lourairo et al, 1979, Loureiro and Macedo, 1986). The Tagus River is currently strongly regulated by over 60 dams (e.g., Fig. 2). Further, it has one of the largest estuaries in Europe, with an area of roughly $320 \mathrm{~km}^{2}$ formed by several channels and islands (Vale et al., 1998) being connected to the sea by a relatively narrow channel (ca. $2 \mathrm{~km}$ width). An estimated amount of $0.4-1$ million tons of suspended material is exported to the adjacent continental shelf annually (Jouanneau et al., 1998). The suspended matter carried by the Tagus River outflow forms a nepheloid layer that is subject to seasonal variations. During summer the surface nepheloid layer is more pronounced and extends up to $14 \mathrm{~km}$ offshore, while during winter the bottom nepheloid layer is more pronounced and stretches over the shelf break (Jouanneau et al., 1998). This is related with the summer upwelling season (May to September) during which the Portugal Coastal Current (PCC) flows southward, induced by the northerly Portuguese trade winds blowing nearly parallel to the coast (e.g., Fiúza et al., 1982; Martins et al., 2002). During the downwelling winter season (October to April), the surface circulation reverses and Portugal Coastal Countercurrent (PCCC) flows southwards close to the coast (e.g., Ambar and Fiúza, 1994).

The Portuguese continental shelf ranges from 20 to $34 \mathrm{~km}$ in width. The shelf break varies between 130 and $150 \mathrm{~m}$ in depth, where several canyons intersect the outer shelf (Mougenot, 1988). The inner shelf is characterized by sands representing the river delta front, with bottom currents strong enough to avoid the deposition of fine-grained particles (Paiva et al., 1997). The decrease of velocity, together with increasing water depth unaffected by waves and storms, allow the deposition of fine particles forming a large muddy shelf sediment body (i.e., the Tagus mud belt) between 50 and $130 \mathrm{~m}$ in depth (Jouanneau et al., 1998). The suspended matter carried by the Tagus River outflow can be transported as far as the Lisbon Canyon (Jouanneau et al., 1998). 
Table 1. Environmental and bulk geochemical data of soils and riverbank sediments collected in the Tagus River basin.

\begin{tabular}{|c|c|c|c|c|c|c|c|c|c|}
\hline $\begin{array}{l}\text { Sample } \\
\text { location }\end{array}$ & $\begin{array}{l}\text { Sampling date } \\
\text { (dd/mm/yyyy) }\end{array}$ & Long. & Lat. & $\begin{array}{r}\text { Altitude } \\
(\mathrm{m})\end{array}$ & Measured pH & $\begin{array}{c}{ }^{\delta^{13} \mathrm{C}_{O C}} \\
(\% \circ \mathrm{VPDB})\end{array}$ & $\begin{array}{r}\text { OC } \\
\text { (wt \%) }\end{array}$ & $\begin{array}{r}\text { MAAT }^{*} \\
\left({ }^{\circ} \mathrm{C}\right)\end{array}$ & $\begin{array}{r}\text { MAP* }^{*} \\
(\mathrm{~mm})\end{array}$ \\
\hline \multicolumn{10}{|l|}{ Soil } \\
\hline 2 & 06/06/2012 & -8.73 & 39.07 & 29 & 5.5 & -27.5 & 5.0 & 17 & 697 \\
\hline 3 & 06/06/2012 & -8.04 & 39.47 & 28 & 6.7 & -27.8 & 3.0 & 17 & 913 \\
\hline 4 & 06/06/2012 & -8.00 & 39.46 & 102 & 5.7 & -27.2 & 0.5 & 16 & 903 \\
\hline 5 & 03/06/2012 & -6.51 & 39.68 & 278 & 6.7 & -28.7 & 0.7 & 16 & 619 \\
\hline 6 & 03/06/2012 & -6.48 & 39.63 & 344 & 7.2 & -28.4 & 2.2 & 16 & 579 \\
\hline 8 & 03/06/2012 & -5.72 & 39.77 & 249 & 6.7 & -29.0 & 0.7 & 17 & 664 \\
\hline 10 & $06 / 06 / 2012$ & -4.65 & 39.94 & 380 & 7.8 & -28.5 & 1.5 & 16 & 504 \\
\hline 12 & 07/06/2012 & -3.57 & 40.04 & 496 & 7.4 & -25.1 & 0.2 & 14 & 508 \\
\hline 13 & 07/06/2012 & -2.97 & 40.26 & 580 & 8.3 & -25.3 & 0.8 & 14 & 465 \\
\hline 14 & 07/06/2012 & -2.96 & 40.27 & 581 & 7.8 & -27.0 & 6.9 & 14 & 475 \\
\hline 15 & 07/06/2012 & -2.91 & 40.42 & 678 & 8.4 & -25.7 & 0.9 & 13 & 517 \\
\hline 16 & 07/06/2012 & -2.84 & 40.51 & 768 & 7.8 & -24.8 & 0.1 & 14 & 491 \\
\hline 17 & 07/06/2012 & -2.59 & 40.70 & 729 & 8.6 & -23.4 & 0.1 & 13 & 595 \\
\hline 18 & 07/06/2012 & -2.28 & 40.67 & 1217 & 8.5 & -25.7 & 0.1 & 10 & 710 \\
\hline 19 & 07/06/2012 & -2.20 & 40.78 & 1100 & 8.4 & -26.1 & 0.1 & 11 & 671 \\
\hline 20 & 07/06/2012 & -2.16 & 40.79 & 931 & 7.6 & -26.8 & 5.8 & 13 & 557 \\
\hline \multicolumn{10}{|c|}{ Riverbank sediment } \\
\hline 1 & 07/06/2012 & -8.98 & 38.95 & 0 & 7.9 & -26.3 & 1.7 & 17 & 677 \\
\hline 3 & 07/06/2012 & -8.04 & 39.47 & 23 & 7.1 & -26.5 & 0.2 & 17 & 913 \\
\hline 7 & 03/06/2012 & -5.74 & 39.76 & 242 & 7.8 & -23.6 & 3.3 & 16 & 858 \\
\hline 7 & 03/06/2012 & -5.74 & 39.76 & 242 & 7.7 & -25.1 & 0.5 & 17 & 656 \\
\hline 9 & 03/06/2012 & -5.68 & 39.84 & 268 & 6.9 & -26.9 & 0.9 & 16 & 758 \\
\hline 9 & 03/06/2012 & -5.68 & 39.84 & 268 & 8.2 & -27.6 & 1.5 & 16 & 758 \\
\hline 11 & 07/06/2012 & -4.02 & 39.86 & 493 & 7.7 & -27.0 & 1.3 & 15 & 386 \\
\hline 13 & $07 / 06 / 2012$ & -2.97 & 40.26 & 580 & 7.4 & -27.1 & 3.0 & 14 & 465 \\
\hline 17 & 07/06/2012 & -2.59 & 40.70 & 717 & 7.8 & -29.6 & 3.7 & 13 & 545 \\
\hline 21 & 07/06/2012 & -2.16 & 40.80 & 901 & 8.0 & -29.8 & 0.6 & 12 & 946 \\
\hline
\end{tabular}

* Data from Ninyerola et al. (2005).

\section{Material and methods}

\subsection{Sample collection}

Top soils (upper $10 \mathrm{~cm}$ ) were sampled in 2012 from upstream to downstream of the Tagus River with the intent of covering the whole altitudinal gradient of the catchment area. The soil sampling sites were generally within a few hundred meters from the river. Exposed riverine sediments, and the upper $10 \mathrm{~cm}$ layer of sediments deposited close to the river shores, were collected as riverbank sediments (Fig. 2, Table 1). Tagus River SPM samples were collected close to the river mouth, each month for a year from July 2011 until June 2012, except for August 2011 (Fig. 2). We filtered 1 to $7 \mathrm{~L}$ of river water on ashed glass-fiber filters (Whatman $\mathrm{GF} / \mathrm{F}, 0.7 \mu \mathrm{m}$ pore size, $142 \mathrm{~mm}$ diameter) for lipid analysis. For organic carbon (OC) and stable carbon isotope analysis of the river SPM, 0.07-0.5 L waters were separately filtered on ashed GF/F filters (Whatman GF/F, $0.7 \mu \mathrm{m}$ pore size, $47 \mathrm{~mm}$ diameter). Marine SPM and surface sediments were collected during the PACEMAKER 64PE332 cruise with the R/V Pelagia between 14 and 29 March 2011. Marine SPM samples were collected at four stations along the Tagus transect from the Tagus estuary mouth towards the deep-sea canyon and at two to five different water depths (Fig. 2b, Table 2). We filtered 64 to $240 \mathrm{~L}$ of seawater over ashed GF/F filters (Whatman GF/F, $0.7 \mu \mathrm{m}$ pore size, $142 \mathrm{~mm}$ diameter) with a McLane in situ pump system (WTS, McLane Labs, Falmouth, MA). For the OC and stable carbon isotope analysis, about $8 \mathrm{~L}$ of seawater were separately filtered on GF/F filters $(0.7 \mu \mathrm{m}$ pore size, $47 \mathrm{~mm}$ diameter). Marine sediment cores were retrieved at six stations using a multicorer developed by Oktopus GmbH. In this study the surface sediments (top $0.5 \mathrm{~cm}$ of the multicores) were used. All samples were frozen immediately after sampling and freeze-dried before analysis. 
Table 2. Environmental and bulk geochemical data of soils and riverbank sediments collected in the Tagus River basin.

\begin{tabular}{|c|c|c|c|c|c|c|c|c|c|}
\hline Sample name & Station & $\begin{array}{l}\text { Sampling date } \\
\text { (dd/mm/yyyy) }\end{array}$ & Long. & Lat. & $\begin{array}{l}\text { Water depth } \\
\text { (m) }\end{array}$ & Measured $\mathrm{pH}$ & $\begin{array}{l}\delta^{13} \mathrm{C}_{\mathrm{OC}} \\
(\% \circ \mathrm{VPDB})\end{array}$ & $\begin{array}{r}\mathrm{OC} \\
(\mathrm{wt} \%)\end{array}$ & $\begin{array}{c}\mathrm{SPM} \\
\left(\mathrm{mg} \mathrm{L}^{-1}\right)\end{array}$ \\
\hline \multicolumn{10}{|l|}{ Tagus River SPM } \\
\hline TR 2\#1 Sup & TR & $12 / 07 / 2011$ & -8.99 & 38.95 & 0 & 8.1 & -29.2 & 2.6 & 74 \\
\hline TR 3\#1 Sup & TR & 16/09/2011 & -8.99 & 38.95 & 0 & 7.9 & -28.4 & 1.8 & 165 \\
\hline TR 4\#1 Sup & TR & $18 / 10 / 2011$ & -8.99 & 38.95 & 0 & 7.4 & -30.9 & 2.5 & 62 \\
\hline TR 7\#1 Sup & TR & $16 / 01 / 2012$ & -8.99 & 38.95 & 0 & 7.9 & -29.8 & 2.4 & 28 \\
\hline TR 8\#1 Sup & TR & $17 / 02 / 2012$ & -8.99 & 38.95 & 0 & 8.0 & -29.4 & 1.0 & 45 \\
\hline TR 9\#1 Sup & TR & $16 / 03 / 2012$ & -8.99 & 38.95 & 0 & 8.1 & -29.0 & 2.2 & 20 \\
\hline TR 10\#1 Sup & TR & $12 / 04 / 2012$ & -8.99 & 38.95 & 0 & 8.1 & -28.5 & 1.9 & 112 \\
\hline TR 11\#1 Sup & TR & $24 / 05 / 2012$ & -8.99 & 38.95 & 0 & 7.9 & -28.5 & 1.7 & 121 \\
\hline TR 12\#1 Sup & $\mathrm{TR}$ & $24 / 06 / 2012$ & -8.99 & 38.95 & 0 & 8.0 & -27.8 & 1.3 & 34 \\
\hline \multicolumn{10}{|l|}{ Marine SPM } \\
\hline 64PE332-27-1-19m & A & $24 / 03 / 2011$ & -9.36 & 38.61 & 19 & - & -25.0 & 2.9 & 2.3 \\
\hline 64PE332-28-3-1m & $\mathrm{C}$ & $24 / 03 / 2011$ & -9.37 & 38.56 & 1 & - & -24.2 & 9.8 & 0.6 \\
\hline 64PE332-28-3-20m & $\mathrm{C}$ & $24 / 03 / 2011$ & -9.37 & 38.56 & 20 & - & -23.8 & 6.8 & 0.9 \\
\hline 64PE332-28-3-50m & $\mathrm{C}$ & $24 / 03 / 2011$ & -9.37 & 38.56 & 50 & - & -23.9 & 5.3 & 0.6 \\
\hline 64PE332-28-3-93m & $\mathrm{C}$ & $24 / 03 / 2011$ & -9.37 & 38.56 & 93 & - & -24.6 & 3.2 & 1.0 \\
\hline 64PE332-32-1-1m & $\mathrm{E}$ & $25 / 03 / 2011$ & -9.43 & 38.39 & 1 & - & -25.8 & 9.6 & 0.5 \\
\hline 64PE332-32-1-50m & $\mathrm{E}$ & $25 / 03 / 2011$ & -9.43 & 38.39 & 50 & - & -24.6 & 10.0 & 0.4 \\
\hline 64PE332-32-1-200m & $\mathrm{E}$ & $25 / 03 / 2011$ & -9.43 & 38.39 & 200 & - & -26.0 & 2.5 & 0.8 \\
\hline 64PE332-32-1-500m & $\mathrm{E}$ & $25 / 03 / 2011$ & -9.43 & 38.39 & 500 & - & -26.2 & 3.4 & 0.4 \\
\hline 64PE332-32-1-1051m & $\mathrm{E}$ & 25/03/2011 & -9.43 & 38.39 & 1051 & - & -26.9 & 3.0 & 0.7 \\
\hline 64PE332-36-4-1m & $\mathrm{F}$ & 27/03/2011 & -9.48 & 38.23 & 1 & - & -24.1 & 9.2 & 0.4 \\
\hline 64PE332-28-1 & $\mathrm{C}$ & $24 / 03 / 2011$ & -9.37 & 38.56 & 94 & - & -24.9 & 1.7 & - \\
\hline 64PE332-31-2 & $\mathrm{D}$ & $25 / 03 / 2011$ & -9.42 & 38.42 & 478 & - & -21.9 & 1.4 & - \\
\hline 64PE332-33-1 & $\mathrm{E}$ & $26 / 03 / 2011$ & -9.43 & 38.39 & 1052 & - & -22.2 & 1.3 & - \\
\hline 64PE332-36-3 & $\mathrm{F}$ & 27/03/2011 & -9.48 & 38.23 & 2432 & - & -22.2 & 0.9 & - \\
\hline
\end{tabular}

“_" = no data

\subsection{Environmental parameters and bulk geochemical analysis}

The $\mathrm{pH}$ of the Tagus River water was measured with a $\mathrm{pH}$ analyzer (Metrohm $\mathrm{pH}-$ meter 744 and combined $\mathrm{pH}$ Electrode LL-Solitrode Pt1000, $\mathrm{pH}$ range $0-14$, T range $-130-200^{\circ} \mathrm{C}$, stored in $3 \mathrm{~mol} \mathrm{~L}^{-1} \mathrm{KCl}$ ). The electrode was calibrated with CertiPUR buffer solutions $(\mathrm{pH} 7.00$ and 9.00); quality control was assured using CertiPUR buffer solutions with $\mathrm{pH} 6.00$ and 8.00 analyzed in parallel with each batch of samples. The measurements were performed in the laboratory within $1 \mathrm{~h}$ of collection. The $\mathrm{pH}$ of the soil and riverbank sediment samples was measured in a mixture with distilled water with a soil to water ratio of $1: 3.5(w: w)$. This mixture was stirred vigorously and left to settle down for $20 \mathrm{~min}$. For the $\mathrm{pH}$ measurements, a $\mathrm{pH}$ analyzer (Wissenschaftlich-Technische Werkstätten $\mathrm{pH}$ $315 \mathrm{i}$ / SET and probe $\mathrm{pH}-E$ lectrode SenTix 41, $\mathrm{pH}$ range 014 , T range $0-80^{\circ} \mathrm{C}$, stored in $3 \mathrm{~mol} \mathrm{~L}^{-1} \mathrm{KCl}$ ) was calibrated 
with CertiPUR buffer solutions with $\mathrm{pH} 4.01,7.00$, and 10.00 .

For the $\mathrm{OC}$ and stable carbon isotope analysis, the riverine and marine SPM filters were decarbonated with $\mathrm{HCl}$ vapor as described by Lorrain et al. (2003). Soils, riverbank sediments, and marine surface sediments were decarbonated with $2 \mathrm{~mol} \mathrm{~L}^{-1} \mathrm{HCl}$ (overnight at $50^{\circ} \mathrm{C}$ ). All samples were analyzed with a Thermo Flash EA 1112 Elemental Analyzer interfaced with a Thermo Finnigan Delta ${ }^{\text {Plus }}$ mass spectrometer. Organic carbon is expressed as the weight percentage of dry sediment (wt \%). The analyses were determined in duplicate and the analytical error was on average better than $0.1 \mathrm{wt} \%$ for the OC content. Isotope values were calibrated to a benzoic acid standard $\left(\delta^{13} \mathrm{C}_{\mathrm{OC}}=-27.8 \%\right.$ with respect to Vienna Pee Dee Belemnite (VPDB) calibrated on NBS22) and corrected for blank contribution. The analytical error was usually smaller than $\pm 0.1 \%$ ofor $\delta^{13} \mathrm{C}_{\mathrm{OC}}$.

\subsection{Lipid extraction and analysis}

The soils and riverbank sediments were extracted using an accelerated solvent extraction (ASE) technique due to the fact that the Bligh and Dyer (BD) method is very time consuming. For the ASE extraction, $2-10 \mathrm{~g}$ freeze dried soils and riverbank sediments were extracted three times using a mixture of dichloromethane (DCM): methanol $(\mathrm{MeOH})$ $(9: 1, v: v)$ at a temperature of $100^{\circ} \mathrm{C}$ and a pressure of 1500 psi (6890 pascal) for 5 min with $60 \%$ flush and purge $60 \mathrm{~s}$. The extract was collected in a vial and solvents were removed using Caliper Turbovab ${ }^{\circledR} \mathrm{LV}$. The total extracts were taken up in DCM, dried over anhydrous $\mathrm{Na}_{2} \mathrm{SO}_{4}$, and blown down under a stream of nitrogen. For GDGT quantification, $0.1 \mu \mathrm{g}$ of an internal standard $\left(\mathrm{C}_{46}\right.$ GDGT; Huguet et al., 2006) was added to the total extracts. The total extracts were separated over an $\mathrm{Al}_{2} \mathrm{O}_{3}$ column (activated for $2 \mathrm{~h}$ at $\left.150^{\circ} \mathrm{C}\right)$ into two fractions using hexane : $\operatorname{DCM}(1: 1, v: v)$, and $\mathrm{DCM}: \mathrm{MeOH}(1: 1, v: v)$, respectively.

In order to analyze both CL and IPL-derived GDGTs, a second extraction method was used, i.e., a modified BD technique (Pitcher et al., 2009). Four soils, four riverbank sediments, and all the river and marine SPM samples and marine surface sediments were extracted with this BD method. In brief, the samples were extracted three times with a single-phase mixture of $\mathrm{MeOH}$ : $\mathrm{DCM}$ : phosphate buffer (2 : $1: 0.8, v: v: v)$ in an ultrasonic bath $(10 \mathrm{~min})$. Extracts and residues were separated each time by centrifugation at $2500 \mathrm{rpm}$ for $5 \mathrm{~min}$. DCM and phosphate buffer were added to the extracts to give a new volume ratio $1: 1: 0.9(v: v: v)$. This mixture was centrifuged at $2500 \mathrm{rpm}$ for $5 \mathrm{~min}$ to obtain a good phase separation. The DCM phase was then collected in a round-bottom flask. The $\mathrm{MeOH}$ : phosphate phase was washed twice with DCM and then discarded. The collected DCM fractions were reduced under rotary vacuum.

The Bligh and Dyer extracts (BDE) were separated into a CL fraction and an IPL fraction over a silica gel (acti- vated for $2 \mathrm{~h}$ at $150^{\circ} \mathrm{C}$ ) column with $n$-hexane : ethyl acetate $(1: 1, v: v)$ and $\mathrm{MeOH}$ as eluents, respectively (Pitcher et al., 2009). For the GDGT quantification, $0.01 \mu, \mathrm{g}$ of $\mathrm{C}_{46}$ GDGT internal standard was added to each fraction. The $\mathrm{CL}$ fractions of the BDEs were separated into three fractions over an $\mathrm{Al}_{2} \mathrm{O}_{3}$ column (activated for $2 \mathrm{~h}$ at $150^{\circ} \mathrm{C}$ ) using hexane : DCM $(9: 1, v: v)$, hexane : $\operatorname{DCM}(1: 1, v: v)$, and DCM : MeOH $(1: 1, v: v)$, respectively. Part of the IPL fraction was hydrolyzed to obtain IPL-derived CLs. The CL polar fractions, the hydrolyzed IPL fractions, and the nonhydrolyzed IPL fractions were analyzed for CL GDGTs. The non-hydrolyzed IPL fractions were also analyzed because it was reported by Pitcher et al. (2009) that during the separation of CL and IPL fractions a small amount of the CL GDGTs was carried over into the IPL fraction. Therefore, it was necessary to implement a correction to more accurately calculate the amounts of CL and IPL-derived GDGTs as described by Weijers et al. (2011).

All samples were analyzed using a high-performance liquid chromatography atmospheric pressure positive ion chemical ionization mass spectrometry (HPLC-APCI-MS) with an Agilent 1100 series LC-MSD SL. The GDGTs were separated on an Alltech Prevail Cyano column $(150 \mathrm{~mm} \times 2.1 \mathrm{~mm} ; 3 \mu \mathrm{m})$ using the method described by Schouten et al. (2007) and modified by Peterse et al. (2012). The compounds were eluted isocratically with $90 \% \mathrm{~A}$ and $10 \% \mathrm{~B}$ for $5 \mathrm{~min}$ at a flow rate of $0.2 \mathrm{~mL} \mathrm{~min}^{-1}$, and then with a linear gradient to $16 \% \mathrm{~B}$ for $34 \mathrm{~min}$, where $\mathrm{A}=$ hexane and $\mathrm{B}=$ hexane : isopropanol $(9: 1, v: v)$. The injection volume was $10 \mu \mathrm{L}$ per sample. Selective ion monitoring of the $[\mathrm{M}+\mathrm{H}]^{+}$of the different brGDGTs and crenarchaeol was used to detect and quantify them. Quantification was achieved by calculating the area of the corresponding peak in the chromatogram and comparing it with the peak area of the internal standard and correcting for the different response factors (Huguet et al., 2006). The analytical error was determined by duplicate measurements of 12 CL GDGTs and 7 IPL-derived brGDGTs fractions. For the concentration of the sum of brGDGTs, the analytical error was $11 \%$ for the CL GDGTs and $6 \%$ for the IPL-derived GDGTs. Crenarchaeol concentrations had a standard deviation of $17 \%$ for the CL GDGTs and $10 \%$ for the IPL-derived GDGTs.

\subsection{Calculation of GDGT-based indices}

The numerals refer to the GDGTs depicted in Fig. 1. The BIT (Hopmans et al., 2004), MBT' (Peterse et al., 2012), and CBT indices (Weijers et al., 2007a), and the degree of cyclization (DC, Sinninghe Damsté et al., 2009) were calculated as follows: 


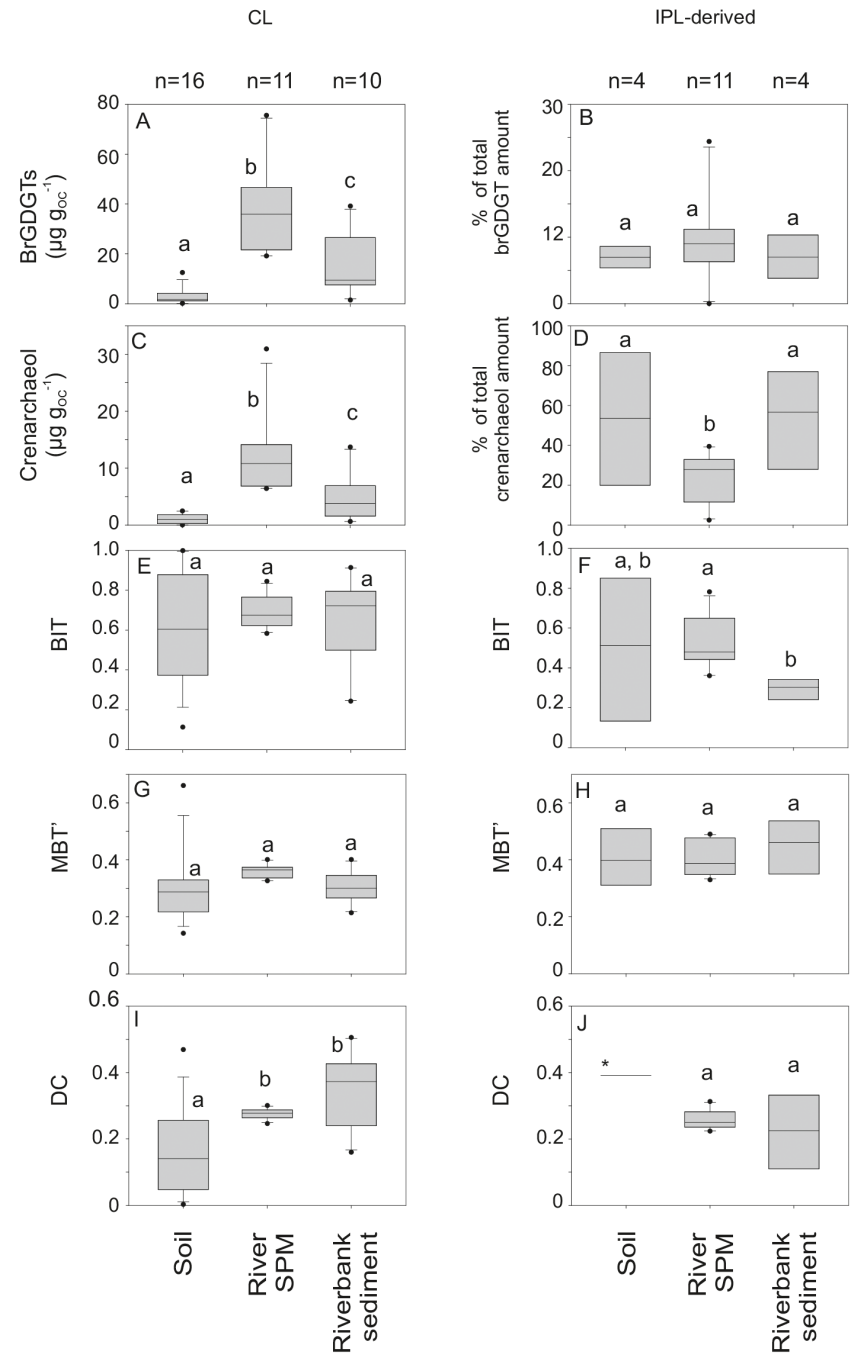

Figure 3. Box plots of (a-d) the CL brGDGT and CL crenarchaeol concentrations and the percentage of IPL-derived brGDGTs and crenarchaeol and (e-j) BIT, MBT', and DC of CL and IPL-derived GDGTs in soils, river SPM, and riverbank sediments; * indicates that the data was available only for one sample.

BITindex $=\frac{[\mathrm{Ia}]+[\mathrm{IIa}]+[\mathrm{IIIa}]}{[\mathrm{Ia}]+[\mathrm{II}]+[\mathrm{III}]+[\mathrm{IV}]}$

$\mathrm{MBT}^{\prime}=\frac{[\mathrm{Ia}]+[\mathrm{Ib}]+[\mathrm{Ic}]}{[\mathrm{Ia}]+[\mathrm{Ib}]+[\mathrm{Ic}]+[\mathrm{IIa}]+[\mathrm{IIb}]+[\mathrm{IIc}]+[\mathrm{IIIa}]}$

$\mathrm{CBT}=-\log \left(\frac{[\mathrm{Ib}]+[\mathrm{II} b]}{[\mathrm{Ia}]+[\mathrm{IIa}]}\right)$

$\mathrm{DC}=\frac{[\mathrm{Ib}]+[\mathrm{IIb}]}{[\mathrm{Ia}]+[\mathrm{Ib}]+[\mathrm{IIa}]+[\mathrm{IIb}]}$

The average standard deviation for the BIT index was 0.01 (CL) and 0.03 (IPL-derived) and for the MBT' 0.01 (CL) and 0.06 (IPL-derived), and for the DC 0.01 (CL) and 0.05 (IPL-derived). For the calculation of $\mathrm{pH}$ and MAAT from the

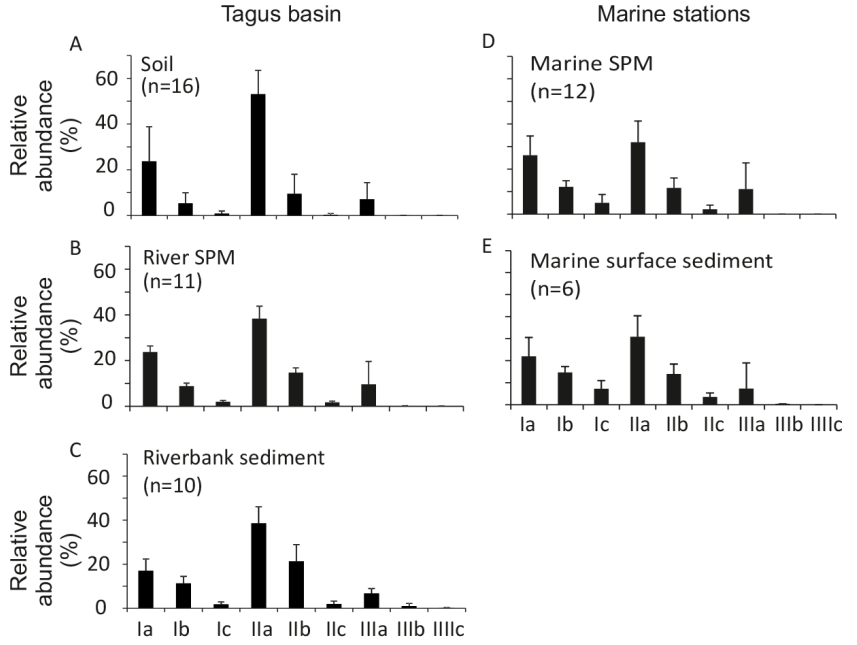

Figure 4. Average CL brGDGT distribution of (a) Tagus soils, (b) Tagus River SPM, (c) riverbank sediments, (d) marine SPM, and (e) marine surface sediments.

brGDGT distribution of soils, sediments, and SPM samples, the global soil calibrations (Peterse et al., 2012) were used:

$$
\begin{aligned}
& \mathrm{pH}=7.90-1.97 \times \mathrm{CBT}\left(r^{2}=0.70\right) \\
& \text { MAAT }=0.81-5.67 \times \mathrm{CBT} \\
& +31: 0 \times \mathrm{MBT}^{\prime}\left(r^{2}=0.59\right)
\end{aligned}
$$

\subsection{Statistical analysis}

To evaluate the differences in mean values between different groups, the non-parametric Mann-Whitney $U$ test was used. Groups that showed significant differences $(p<0.05)$ were assigned different letters. The statistical test was performed with SigmaPlot.

\section{Results}

\subsection{Tagus soils}

Sixteen soil samples that were collected along the Tagus River (Fig. 2) were analyzed. The OC content ranged from 0.1 to $6.9 \mathrm{wt} \%$ and the $\delta^{13} \mathrm{C}_{\mathrm{OC}}$ was $-26.7 \pm 1.6 \%$ o (average \pm standard deviation $[1 \sigma]$ ) (Table 1). Soil pH was on average $7.4 \pm 1.0$ (Table 1). Core lipid brGDGTs were found in all soils with an average concentration of $3.2 \pm 3.4 \mu \mathrm{g} \mathrm{g}_{\mathrm{OC}}^{-1}$ (Fig. 3a). Of the four soils for which IPLderived brGDGTs were measured, $7 \pm 2 \%$ of the total brGDGTs amount was IPL-derived (Fig. 3b). The distribution of CL brGDGTs strongly varied between the soils, but brGDGT IIa $(53 \pm 10 \%)$ and Ia $(24 \pm 15 \%)$ were in general the most abundant compounds (Fig. 4a). The BIT index was $0.62 \pm 0.28$ in the CL GDGTs and $0.50 \pm 0.38$ in the IPL-derived GDGTs (Fig. 3e, f). The CL MBT' 

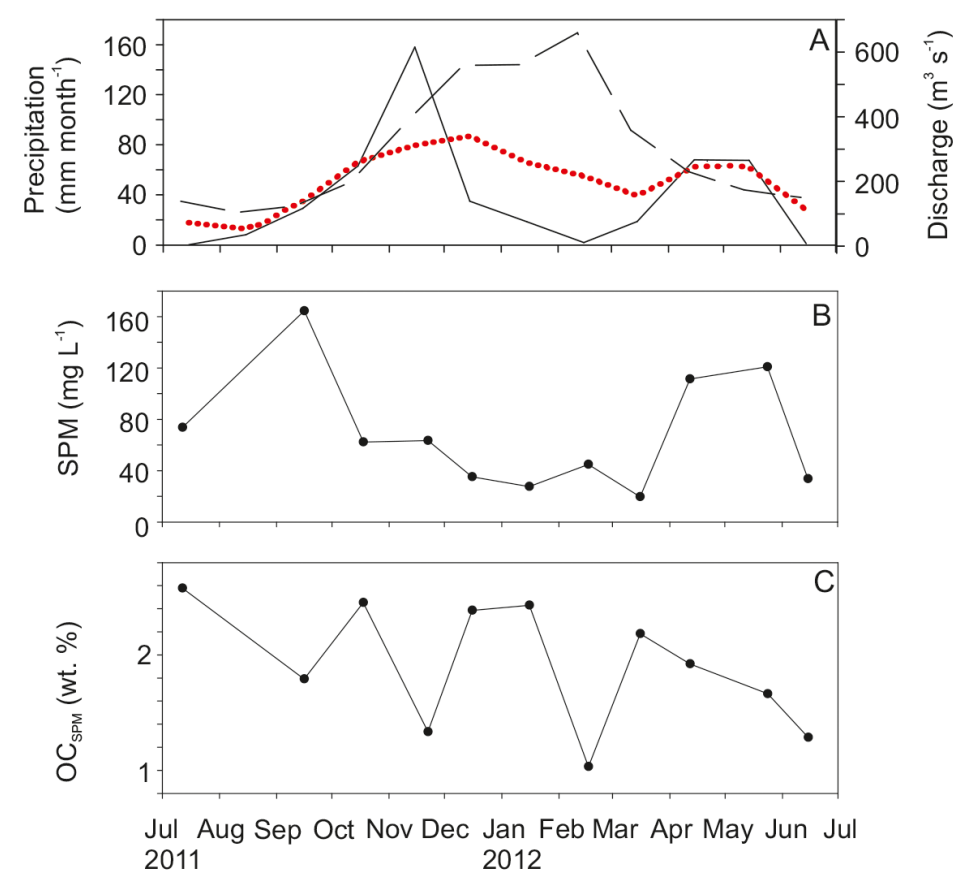

Precipitation Spanish Tagus basin

... Average $1971-2000$

Precipitation Portuguese Tagus basin

- 2011-2012

Tagus River discharge at Almourol station —_ Average 1990-2013

Figure 5. Mean monthly precipitation in the Portuguese and Spanish parts of the Tagus River basin and the Tagus River discharge at Almourol station (data source: Sistema Nacional de Informaçião de Recursos Hídricos) (a), SPM concentration at the Tagus River station (b), and the amount of OC in the SPM (wt \%) of the Tagus River (c).

was $0.30 \pm 0.13$ and the CL DC $0.16 \pm 0.13$ (Fig. 3g). The MBT' of IPL-derived brGDGTs was $0.41 \pm 0.11$ (Fig. 3h). Only in the soil from location 18 was the concentration of IPL-derived-brGDGTs sufficiently high to calculate the DC, which was 0.39 (Fig. 3g-j). Core lipid crenarchaeol concentration in soils was on average $1.1 \pm 0.8 \mu \mathrm{g} \mathrm{g}-1$ aC a substantial amount $(53 \pm 36 \%)$ of the total crenarchaeol amount was IPL-derived (Fig. 3c, d).

The CL brGDGT and CL crenarchaeol concentrations obtained by ASE extraction were on average $4.6 \mu \mathrm{g} \mathrm{g}_{\mathrm{OC}}^{-1}$ and $1.5 \mu \mathrm{g} \mathrm{g}_{\mathrm{OC}}^{-1}$, respectively, higher than with the BD method. Furthermore, the BIT index was on average 0.08 lower, the MBT' 0.01 higher, and the DC 0.02 higher in ASE extracted samples compared to BD extracted samples. This shows that the CL fractions extracted by BD and the GDGTs extracted by ASE gave similar results, which is why they were treated as comparable results in the discussion.

\subsection{Tagus River SPM}

The $\mathrm{pH}$ of the river water was relatively constant at $7.4 \pm 0.1$ over the annual cycle, and the amount of SPM in the river water ranged from 28 to $165 \mathrm{mg} \mathrm{L}^{-1}$ (Fig. $5 \mathrm{~b}$; Table 2). The OC content of SPM varied between 1.0 and $2.6 \mathrm{wt} \%$ and the $\delta^{13} \mathrm{COC}_{\mathrm{OC}}$ was $-29.1 \pm 0.8 \%$ (Table 2). The average CL brGDGT concentration was $43 \pm 16 \mu \mathrm{g} \mathrm{g}_{\mathrm{OC}}^{-1}$ and the percentage of IPL-derived brGDGTs was $12 \pm 8$ (Fig. 3a, b). The CL brGDGT distribution in river SPM was more uniform compared to those of the soils and the riverbank sediments (Fig. 4b). The most abundant CL brGDGTs were brGDGT IIa $(39 \pm 5 \%)$ and Ia $(24 \pm 3 \%)$ but with more abundant brGDGT IIIa $(10 \pm 10 \%)$ than in the soils. The crenarchaeol concentration was on average $13 \pm 6 \mu \mathrm{g} \mathrm{g}_{\mathrm{OC}}^{-1}$ and the percentage of IPL-derived crenarchaeol was $23 \pm 13$ (Fig. 3c, d). This resulted in a BIT index of $0.71 \pm 0.08$ in the CL fractions and of $0.56 \pm 0.13$ in the IPL-derived fractions (Fig. 3e, f). The average CL MBT' and DC values were $0.35 \pm 0.04$ and $0.28 \pm 0.02$, respectively, while the average IPL-derived MBT' and DC values were $0.40 \pm 0.05$ and $0.27 \pm 0.04$, respectively (Fig. $3 \mathrm{~g}-\mathrm{j}$ ). The brGDGT and crenarchaeol concentrations in the Tagus River SPM fluctuated over the year; the highest concentrations (in $\mathrm{ng} \mathrm{L}^{-1}$ ) were seen in September and May (Fig. 6a). The brGDGT concentrations normalized to OC were highest in November and December, while crenarchaeol concentrations normalized to OC were highest in February-June (Fig. 6b). The highest percentage of IPLderived brGDGTs was found in March and that for crenarchaeol in January and February (Fig. 6c). The CL BIT increased in November, while the CL MBT' and DC decreased in November (Fig. 7). IPL-derived BIT, MBT', and DC all increased in March and April.

\subsection{Tagus riverbank sediments}

Ten riverbank sediments were analyzed. The OC content ranged from 0.2 to $3.7 \mathrm{wt} \%$, the $\delta^{13} \mathrm{C}_{\mathrm{OC}}$ from -23.6 to $-28.6 \%$, and the $\mathrm{pH}$ from 6.9 to 8.2 (Table 1). Core lipid 
BrGDGTs

A

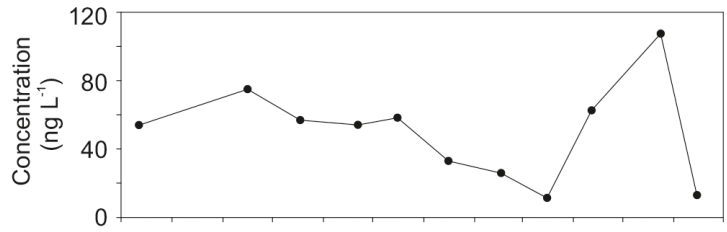

B

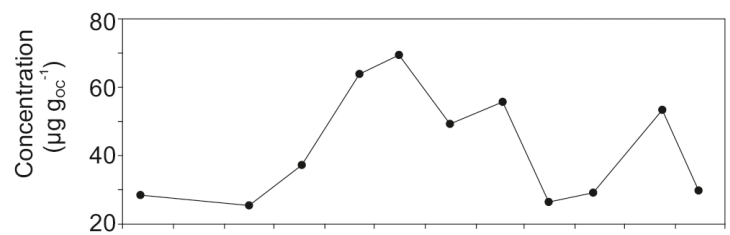

C

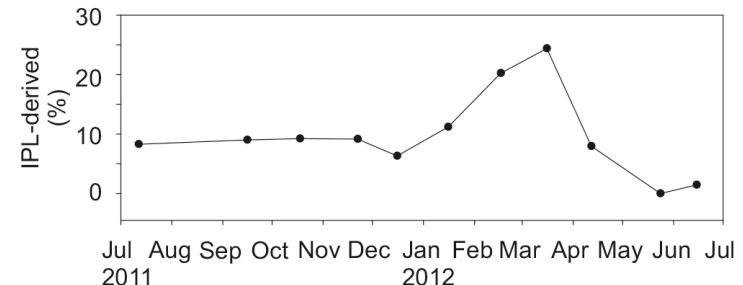

Crenarchaeol
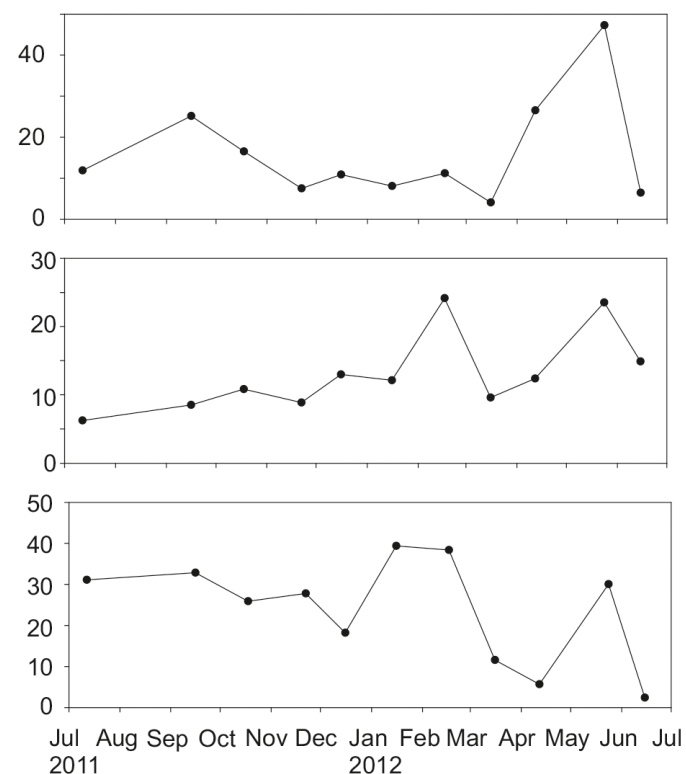

Figure 6. Variations in CL brGDGT and CL crenarchaeol concentrations and the percentage of IPL-derived brGDGTs and crenarchaeol in Tagus SPM over a year (2011-2012).

$\mathrm{CL}$

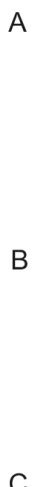

C

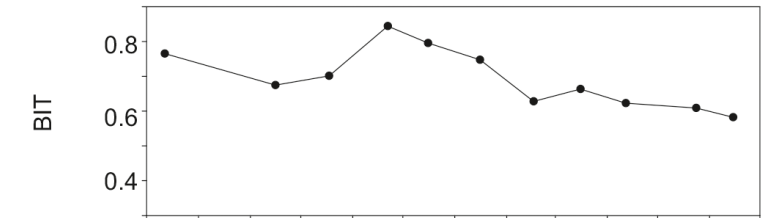

B
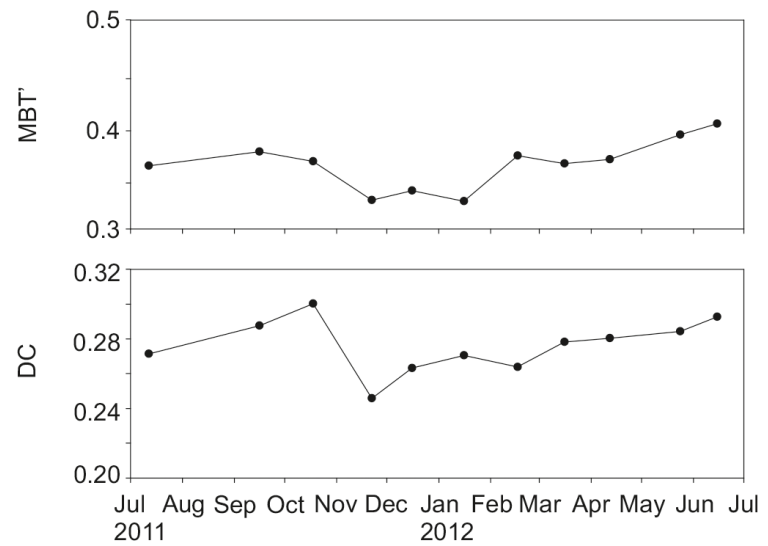

IPL-derived
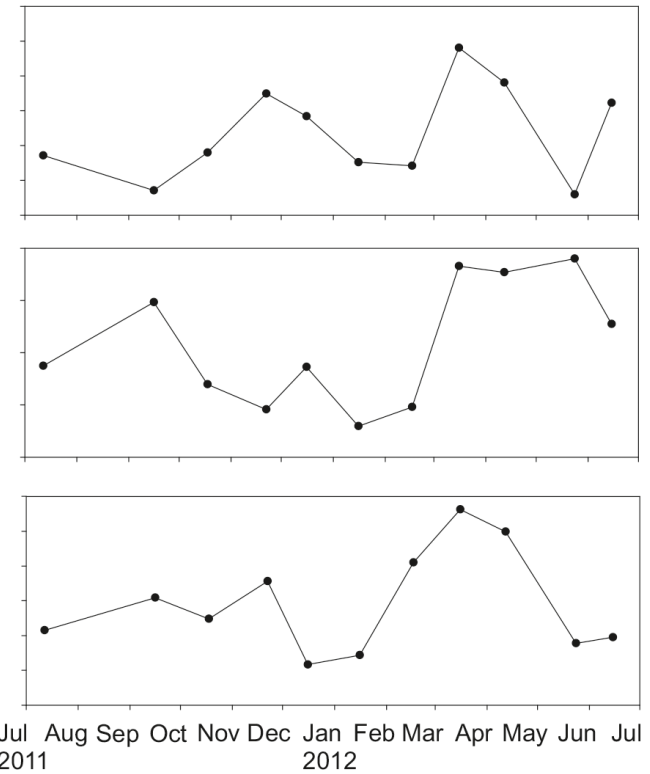

Figure 7. Variations in CL and IPL-derived BIT, MBT', and DC in Tagus SPM over a year (2011-2012).

brGDGTs were present with an average concentration of $15.2 \pm 11.9 \mu \mathrm{g} \mathrm{g}_{\mathrm{OC}}^{-1}$ (Fig. 3a). For four riverbank sediments, the IPL-derived brGDGTs were also measured: $7 \pm 3 \%$ of the total brGDGTs amount were IPL-derived (Fig. 3b). The average distribution of CL brGDGTs (Fig. 4c) revealed that brGDGT IIa $(39 \pm 7 \%)$ and Ia $(17 \pm 5 \%)$ were the most abundant compounds. Core lipid crenarchaeol concentra- tion in riverbank sediments was on average $4.7 \pm 4.7 \mu \mathrm{g} \mathrm{g}_{\mathrm{OC}}^{-1}$, and $54 \pm 26 \%$ of the total crenarchaeol amount was IPLderived (Fig. 3c, d). The BIT index was $0.65 \pm 0.23$ in the CL GDGTs and $0.30 \pm 0.05$ in the IPL-derived GDGTs (Fig. 3e, f). The CL MBT' was $0.31 \pm 0.05$ and the CL DC $0.37 \pm 0.11$. The MBT' and DC of IPL-derived brGDGTs 

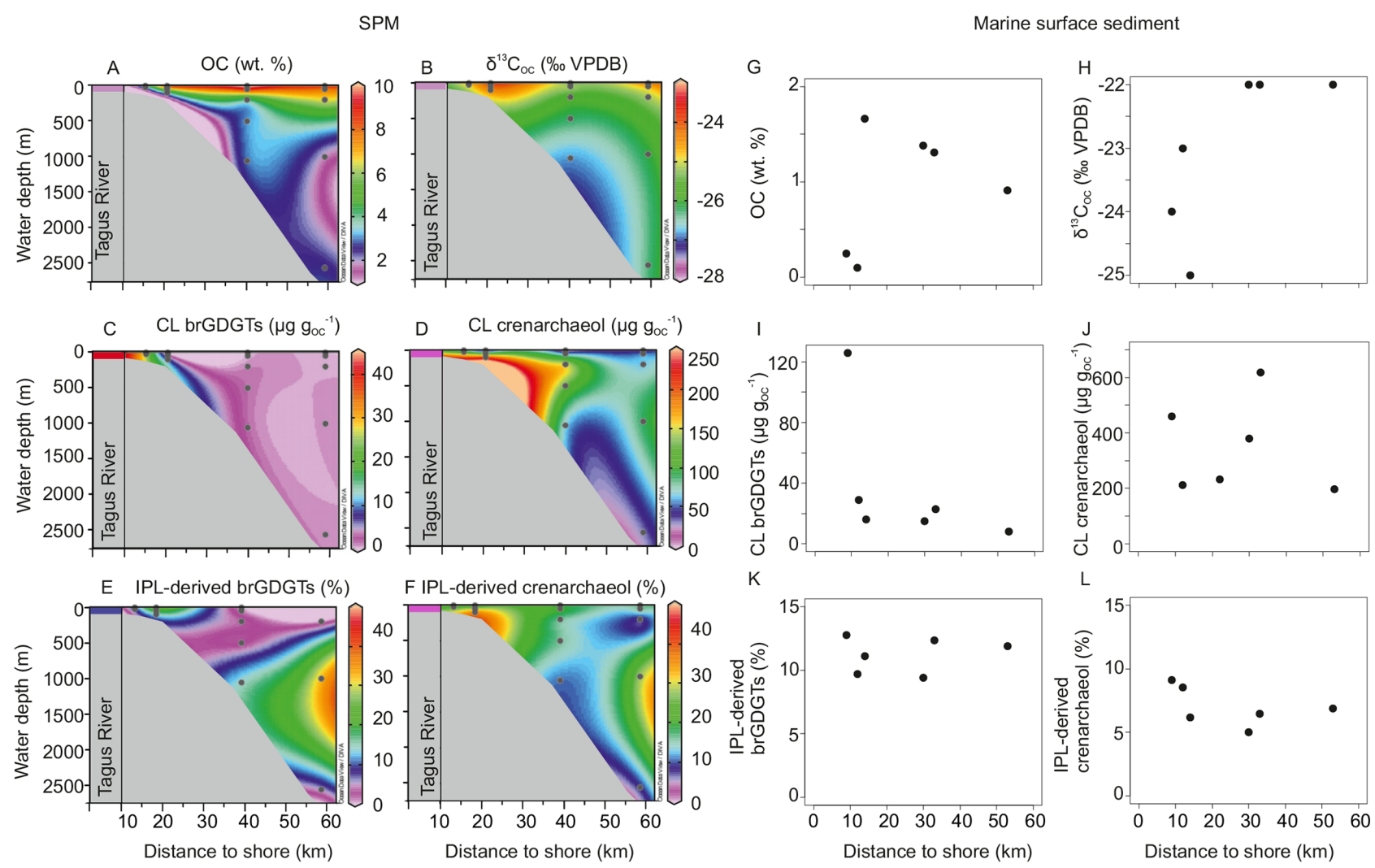

Figure 8. OC content, $\delta^{13} \mathrm{C}_{\mathrm{OC}}$, CL brGDGT and CL crenarchaeol concentrations, and the percentage of IPL-derived brGDGTs and crenarchaeol for marine SPM (a-f) and for marine surface sediments (g-l). The average values of the Tagus River SPM are also shown.

were on average $0.45 \pm 0.10$ and $0.22 \pm 0.12$, respectively (Fig. 3g-j).

\subsection{Marine SPM}

The amount of SPM in marine water varied between 0.6 and $2.3 \mathrm{mg} \mathrm{L}^{-1}$, with the higher values closest to the estuary mouth (Table 2). The OC content of the SPM ranged from 1.6 to $10 \mathrm{wt} \%$ and the $\delta^{13} \mathrm{C}_{\mathrm{OC}}$ from -24.1 to $-26.9 \%$ (Table 2). In general, the OC content of SPM was higher in surface waters than in bottom waters (Fig. 8a), and $\delta^{13} \mathrm{C}_{\mathrm{OC}}$ was more enriched in surface waters compared to bottom waters (Fig. 8b). The CL brGDGT concentrations varied widely between 0.06 and $31 \mu \mathrm{g} \mathrm{g}-1$ with an average amount of $4 \pm 9$ $\mu \mathrm{gg}_{\mathrm{OC}}^{-1}$. The percentage of IPL-derived brGDGTs of the total amount of brGDGTs was $15 \pm 13$. Core lipid brGDGT concentrations decreased from the estuary mouth towards the deep-sea canyon (Fig. 8c). The highest concentration was found in the surface water at the shallowest station A $\left(31 \mu \mathrm{g} \mathrm{g}_{\mathrm{OC}}^{-1}\right)$. The CL brGDGTs were not detectable in the surface water of the canyon station furthest away from the estuary mouth (station F). In all stations but the one closest to the estuary mouth, higher brGDGT concentrations were found in the bottom waters than in surface waters (Fig. 8c). The most abundant CL brGDGTs were IIa $(32 \pm 10 \%)$ and
Ia $(26 \pm 9 \%)$ (Fig. 4d). Core lipid crenarchaeol concentrations varied between 82 and $242 \mu \mathrm{gg}_{\mathrm{OC}}^{-1}$ (Fig. $8 \mathrm{~d}$ ). The percentage of IPL-derived crenarchaeol was $20 \pm 10$. The BIT index ranged between $<0.01$ and 0.18 with an average CL BIT of $0.03 \pm 0.06$ and IPL-derived BIT $0.02 \pm 0.03$. The highest BIT values were measured closest to the estuary mouth (Fig. 9a, b).

Due to low CL and IPL-derived brGDGT concentrations, MBT' and DC could not be calculated for all SPM samples because not all of the necessary brGDGTs were detected. The MBT' and DC of CL brGDGTs were $0.49 \pm 0.06$ and $0.26 \pm 0.14$, respectively. For IPL-derived brGDGTs, the MBT' and DC were $0.54 \pm 0.14$ and $0.13 \pm 0.13$, respectively (Fig. 9c-f).

\subsection{Marine surface sediments}

The marine surface sediments had average OC content between 0.01 and $1.7 \mathrm{wt} \%$ and the $\delta^{13} \mathrm{C}_{\mathrm{OC}}$ values varied between -21.9 and $-24.4 \%$ (Table 2; Fig. 8g-h). The CL brGDGT concentrations (Fig. 8i) were higher at stations close to the estuary mouth (stations A-C), with values declining from 130 to $16 \mu \mathrm{g} \mathrm{g}_{\mathrm{OC}}^{-1}$. The surface sediments from the offshore stations D-F had lower concentrations (between $\left.23-7 \mu \mathrm{g} \mathrm{g}_{\mathrm{OC}}^{-1}\right)$. The percentage of IPL-derived brGDGTs was 
SPM

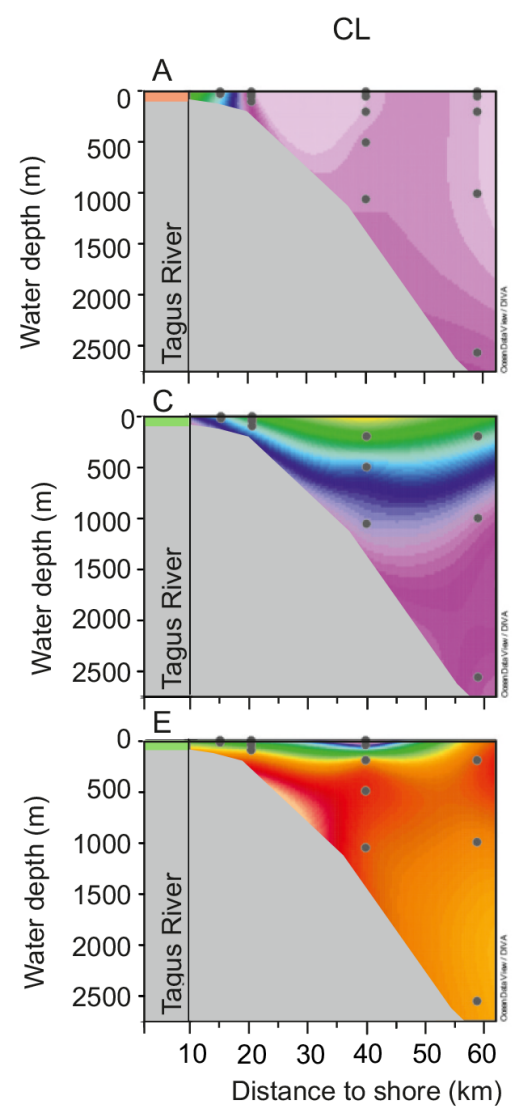

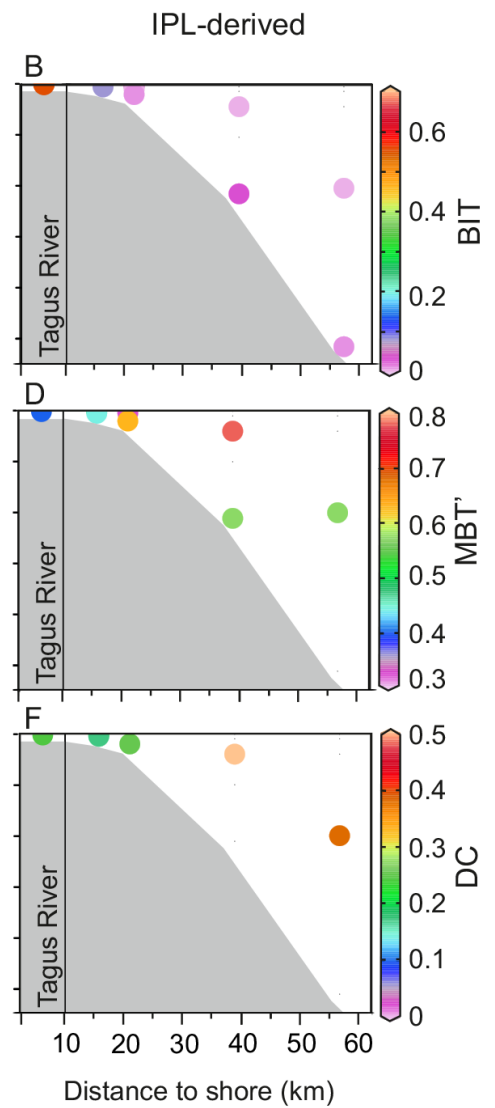

Marine surface sediment

G

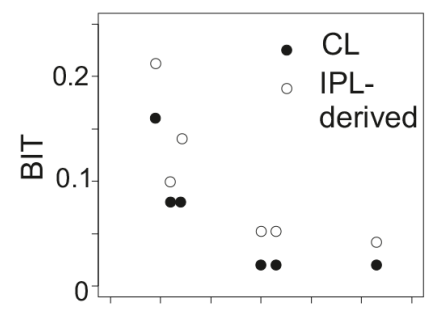

$\mathrm{H}$

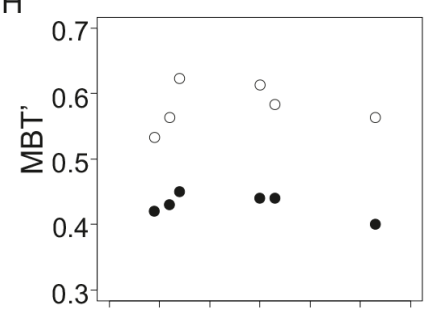

I

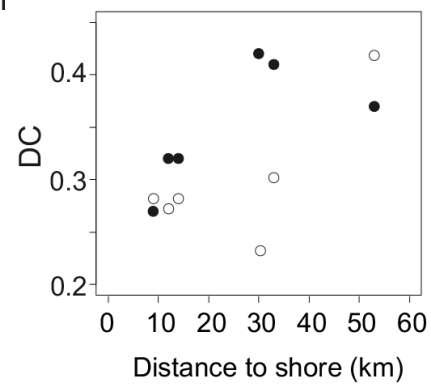

Figure 9. BIT, MBT', and DC of CL and IPL-derived GDGTs (a-f) for marine SPM and (g-i) for marine surface sediments. The average values of the Tagus River SPM were also shown.

on average $11 \pm 1$. The most abundant brGDGTs were IIa $(31 \pm 5 \%)$ and Ia (22 $\pm 3 \%)$ (Fig. 4e). The crenarchaeol concentrations varied between 120 and $600 \mu \mathrm{g} \mathrm{g}_{\mathrm{OC}}^{-1}$ (Fig. 8j). The percentage of IPL-derived crenarchaeol was $7 \pm 2$ (Fig. 81). The BIT index varied between 0.16 and 0.02 in the CL fractions and 0.21 and 0.04 in the IPL-derived fractions, with a clear decreasing trend towards the deep-sea canyon station (Fig. 9g). The average CL MBT' was $0.43 \pm 0.02$ and the CL DC was $0.35 \pm 0.06$. The MBT' of the IPLderived brGDGTs was on average $0.58 \pm 0.03$ and the DC $0.30 \pm 0.06$. For both CL and IPL-derived fractions, MBT' did not show a trend with increasing distance from the coast (Fig. 9h), whereas DC showed a trend toward higher values (Fig. 9i).

\section{Discussion}

\subsection{Characteristics of the bulk organic matter}

The organic matter content of soil in dry and warm climates is usually low (Jobbágy and Jackson, 2000), which is also observed in the Tagus basin (on average $1.8 \pm 2.2 \mathrm{wt} \%$, Table 1). In river SPM, the OC content was similar to that of soil and relatively constant around the year (on average $1.9 \pm 0.5 \mathrm{wt} \%$ ) (Fig. 5c, Table 1). The $\delta^{13} \mathrm{C}_{\mathrm{OC}}$ values of soils $(-26.7 \pm 1.6 \%$ ) , riverbank sediments $(-26.9 \pm 1.8 \%$ o $)$, and river SPM $\left(-29.1 \pm 0.8 \%\right.$ o ) show a typical $\mathrm{C}_{3}$ higher-plantdominated signal (e.g., Fry and Sherr, 1984). The lower values of the SPM might indicate a prevalent input of soils from the downstream part of the river $(-28.2 \pm 0.6 \%$ o soil from location 2-10; Table 2), which are in closer vicinity to the SPM sampling site. In marine SPM and surface sediments, the ${ }^{13} \mathrm{C}_{\mathrm{OC}}$ values (on average $-25.1 \pm 2 \%$ and $-23.1 \pm 2 \%$, respectively) were higher in comparison to those of the Tagus basin samples and increased from inshore to offshore (Fig. 8a and $h$ ). This suggests that the proportion of marine-derived OC to the total OC pool increased from close to the Tagus estuary to the deep-sea canyon site. In general, salinity (unpublished data) was lower and much more variable on the shelf than on the continental slope and deep-sea canyons, which indicated the predominant influence of the Tagus River outflow on the shelf. This is in good agreement with the higher proportion of terrestrial OC in the shelf sediments and SPM. 
A

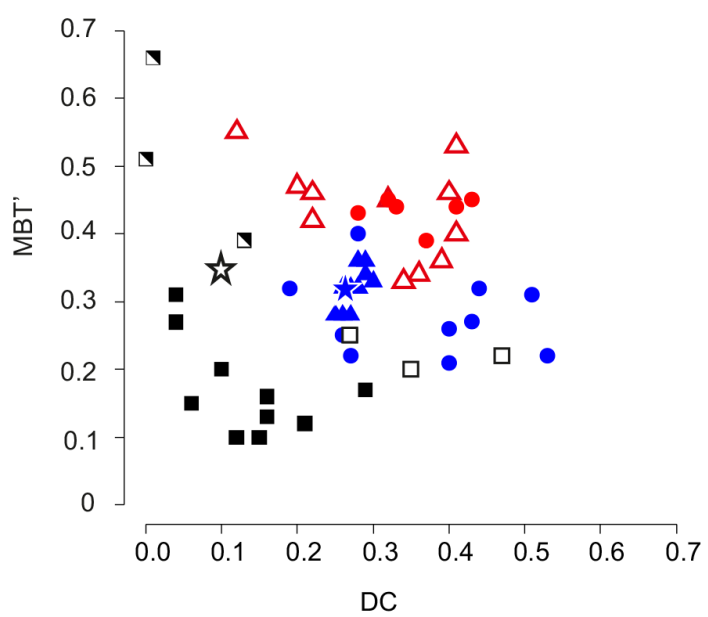

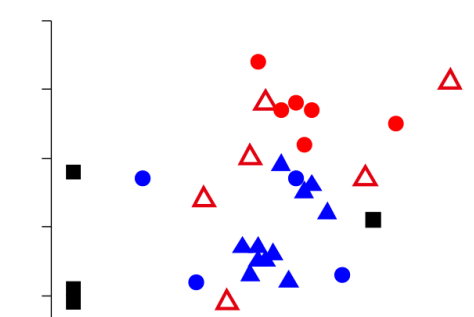

- Soil between 200 and $900 \mathrm{~m}$ alt.
$\square$ Soil above $900 \mathrm{~m}$ alt.
$\square$ Soil below $200 \mathrm{~m}$ alt.

- River SPM

- Riverbank sediment

$\triangle$ Marine SPM

- Marine surface sediment

Figure 10. Scatter plots of MBT' vs. DC for (a) CL and (b) IPL-derived brGDGTs in all sample types and the weighted average MBT' and DC of the soil and river SPM samples.

In addition, a higher OC content of SPM was recorded in the upper water layers where marine primary production takes place.

In the marine sediment sampled close to the river estuary, the OC content was lower than in the open ocean (Fig. 8g). Jouanneau et al. (1998), who studied the OC contents in marine sediments of this area in more detail, also showed that the OC content was low close to the river estuary. This is because the OC content was closely related to the sediment grain size, and the average grain size of the surface sediments was larger close to the river estuary. Therefore, the OC content of surface sediments increased towards the mud belt at $100 \mathrm{~m}$ in depth. The OC content may also increase at greater water depths due to marine production. Our $\delta^{13} \mathrm{COC}_{\mathrm{OC}}$ data from the marine surface sediments indicate that the majority of the $\mathrm{OC}$ on the Portuguese shelf is of marine origin. Even in the estuary, only 50 to $65 \%$ of OC content is estimated to be of terrestrial origin (Alt-Epping et al., 2007). The Tagus River acts mainly as a supplier of terrigenous lithogenic particles to the coastal ocean, while the majority of the terrestrial organic matter is retained inside the estuary (Jouanneau et al., 1998).

\subsection{GDGTs in soils of the Tagus drainage basin}

BrGDGTs and crenarchaeol were found in all Tagus soils. The relative amount of brGDGTs to crenarchaeol, which is defined in the BIT index, was relatively low (BIT $=0.7 \pm 0.2$ ) compared to soils in general (cf. Schouten et al., 2013 for an overview). It has been reported in several studies that the BIT decreases with increasing soil $\mathrm{pH}$ and is lower and more variable above a pH of 5.5 (Kim et al., 2010; Peterse et al., 2010; Yang et al., 2011). Indeed the pH of all but one of the soils studied were above 5.5. Recently, reduced values of the BIT index in soils have also been attributed to a dry climate (Xie et al., 2012; Dirghangi et al., 2013; Menges et al., 2014). The reason for the low BIT could be that in dry soils, oxygen can penetrate further into the soil (Cleveland et al., 2010). Xie et al. (2012) suggested that oxic conditions might be unfavorable for the facultative anaerobic brGDGTproducing bacteria, but may be beneficial for nitrifying (i.e., requiring oxygen) Thaumarchaeota, increasing crenarchaeol productions in soils.

The distribution of the brGDGTs varied strongly in the Tagus basin soils (Fig. 4), which led to highly variable MBT' and DC (or CBT) values (Fig. 10a). There was no correlation between the MBT' and the MAAT, like in the global soil data set (Peterse et al., 2012). Further, the reconstructed MAAT in the Tagus basin soils was much lower in the Tagus basin soils $\left(0-10^{\circ} \mathrm{C}\right)$ than the measured MAAT $\left(10-17^{\circ} \mathrm{C}\right.$, see Table 1). However, it has been previously described that the MBT' shows a less strong relationship with MAAT in dry areas (mean annual precipitation (MAP) $<700-800 \mathrm{~mm} \mathrm{yr}^{-1}$ ) than in other climate regions (Peterse et al., 2012; Xie, 2012; Dirghangi et al., 2013). The MAP at the sampling sites is indeed low at $450-910 \mathrm{~mm} \mathrm{yr}^{-1}$ (Table 1). A recent study of 23 Iberian soils (Menges et al., 2014) has revealed similar 
variable MBT' and DC (or CBT) values to those we report here. In that study it is suggested that the MBT' is primarily related with the MAP and soil aridity. In our data set the soils from $>900 \mathrm{~m}$ altitude showed a higher DC (i.e., $>0.3$ ) compared to the rest of the soils, while those collected $<200 \mathrm{~m}$ altitude showed a relatively low DC (i.e., $<0.15$ ) and a higher MBT' (i.e., > 0.4) (Fig. 10a). However, we did not observe a clear correlation of the DC and MBT' with altitude. The brGDGT composition in soils of the Tagus River watershed was thus quite variable. Soils are notoriously heterogeneous in composition (e.g., Williams et al., 2002) and the fact that the Tagus River basin is in an arid climate zone may further contribute to this poor correlation. Despite the variability of brGDGT distributions in Iberian soils, we will compare them with those in the river system to test if they are an important source for riverine brGDGTs.

\subsection{Sources of GDGTs in Tagus River SPM and riverbank sediments}

Compared to soils, significantly higher concentrations (normalized to $\mathrm{OC}$ to account for differences in grain size) of both CL brGDGTs and CL crenarchaeol were found in river SPM (Fig. 3a and c). Higher crenarchaeol concentrations are expected since crenarchaeol is usually produced in higher amounts relative to brGDGTs in aquatic environments (Herfort et al. 2006; Kim et al. 2010). For riverine brGDGTs it is originally assumed that they originate from surrounding soils (Hopmans et al., 2004). Consequently, it would be expected that riverine brGDGTs have similar concentrations and distributions as the soils in the watershed of the river. The significantly higher CL brGDGT concentration in river SPM than in soils thus suggests that brGDGTs were also produced in situ in the Tagus River. This could be revealed by a relatively high amount of brGDGTs with polar head groups (cf. Peterse et al., 2011b). The percentage of IPL-derived brGDGTs in river SPM was not significantly higher than in soils (Fig. 3b). However, if riverine brGDGTs would only derive from soil erosion, one would expect this number to drop since labile IPL brGDGTs would be preferentially broken down during transport.

A third line of evidence for in situ production in the river comes from the distribution of brGDGTs (Fig. 4). If riverine brGDGTs are derived from two different sources, this can also often be detected in the brGDGT distribution. We compared the brGDGT distribution with the help of the MBT' and DC (Fig. 10a). In order to examine what MBT' and DC values a mixture of the brGDGTs from the drainage basin soils would theoretically have, we calculated a brGDGTconcentration-weighted MBT' and DC. This is based on the assumption that soils that contain a higher concentration of brGDGTs will contribute more to the average input of brGDGTs from soils into the river. The weighted CL MBT' and CL DC values were 0.36 and 0.10 , respectively (Fig. 10a). The DC value is substantially different from that of riverine SPM (Fig. 10a). It has to be considered that this average soil value is substantially influenced by the soils from location 2 and 3 (both from $<200 \mathrm{~m}$ altitude) because they have much higher brGDGT concentrations compared to all other soils (together they make up for $\approx 60 \%$ of the weighted average). These high brGDGT concentrations may bias the weighted average. However, considering that the Tagus River has many dams, which hold back the SPM from the upper basin, the soils from the lower basin $(<200 \mathrm{~m}$ altitude) most likely have a much higher impact on the brGDGTs found in the SPM collected close to the river mouth. Irrespectively, as the calculated soil average is representative for the soil-derived brGDGTs at the SPM sampling site, Fig. 10a shows that the DC in river SPM is substantially higher (i.e., 0.28 versus 0.10 ) than the DC in the majority of the soils and especially of those in the lower basin. This is again an indication that brGDGTs are predominantly produced in the river.

In a study of brGDGTs in SPM of the Amazon River (Brazil), it was shown that the brGDGT concentration and distribution can be influenced by hydrological changes, meaning that during times of increased precipitation, higher amounts of brGDGTs are washed into the river from soils (Zell et al., 2013b). This influences the brGDGT distribution in rivers because it affects the amount of soil-derived relative to in situ produced brGDGTs in the river. In addition, the brGDGTs produced in the river might reflect environmental conditions in the river that change over the annual cycle. We evaluated temporal variations in the brGDGT composition of the SPM (sampled close to the river mouth) to shed further light on the potential origins of brGDGTs. The Iberian Peninsula is typically characterized by a period of higher precipitation from October to March and thus higher Tagus River discharge (Fig. 5a). However, during the SPM sampling period (2011-2012) the Iberian Peninsula experienced a relatively dry winter (Trigo et al., 2012). A profound increase in precipitation is evident for October and November, but December and March were unusually dry (Fig. 5a). This precipitation pattern does not show a clear relationship with the SPM concentration profile (Fig. 5b) and the concentration of brGDGTs (Fig. 6a, b) as would be expected if increased precipitation would result in increased soil erosion and subsequent input in the river system; however, it should be noted that we did not measure the SPM and brGDGT fluxes. A further complication is that the Tagus River is strongly regulated with dams that are used to provide drinking water and water for agricultural purposes to Spain and Portugal and also to generate hydroelectricity. Therefore, the flow through the river is not only influenced by precipitation. In terms of compositional changes in SPM, it is noteworthy that at the peak of maximum precipitation in November 2011, the BIT index is at a maximum (0.84) and the DC of the brGDGT shows the lowest value $(0.25)$. This could be interpreted as an increased contribution of soil-derived brGDGTs although the value for the DC is still far away from the average for soils in 
the watershed $(0.10-0.11$; Fig. 10c). With respect to the temporal changes in the MBT', the lowest values are recorded for November-March (Fig. 10b), with the largest changes observed for the IPL-derived brGDGTs. MBT' (and MBT) are also related to temperature in aquatic systems (Tierney et al., 2010; Zink et al., 2010; Pearson et al., 2011; Sun et al., 2011). Hence, MBT' could be used as evidence for in situ production of brGDGTs in the river as MBT' would then follow the changes in temperature over the annual cycle, whereas in case of a dominant soil origin for the brGDGTs, this would not be expected because of their residence time in soils (Weijers et al., 2011). Our data show that seasonal hydrological changes may have an influence on the brGDGT distribution in the Tagus River, but these changes are not evident enough to make an estimate of the contributions of the two sources for brGDGTs in this river system.

Compared to the SPM, which was only sampled close to the river mouth, riverbank sediments were sampled at several stations along the river. In most of the riverbank sediment, the DC was higher than in river SPM. However, the MBT' and DC of the riverbank sediment close to the river mouth (samples 6 and 8a) were similar to those of the river SPM, which was also collected close to the river mouth. This shows that the DC of brGDGTs most likely varies along the river. Numerous dams in the Tagus River hold back the sediment from the upstream parts and, thereby, they might decrease the influence of brGDGTs from the upstream drainage basin on the downstream river.

\subsection{Sources of GDGTs in marine SPM and surface sediments}

It should be considered that the results from the marine SPM only give a "snapshot" at the moment of sampling (i.e., March 2011, chosen to reflect the end of the season with highest amount of rainfall) and should, thus, be interpreted cautiously. The crenarchaeol concentrations were higher in marine SPM and surface sediments than in river SPM, which shows that marine Thaumarchaeota were the predominant source of crenarchaeol in the marine environment. In SPM, IPL-derived crenarchaeol was higher than in sediments (Fig. 8f and 1), suggesting that crenarchaeol production takes place predominantly in the water column. In the marine sediment the crenarchaeol concentration showed no clear trend from land to ocean (Fig. 8j). At the time of sampling the input of brGDGTs from the river into the marine system was evident. Higher CL brGDGT concentrations were detected at the stations $(\mathrm{A}-\mathrm{C})$ close to the river estuary, but these concentrations were already lower than those in river SPM (Fig. 8c). At these stations, the highest CL brGDGT concentrations were found in the bottom-water SPM as compared to shallow-water SPM (Fig. 8c). This may indicate that the brGDGTs in river SPM are (partially) transported by a bottom nepheloid layer. This terrestrial input to the bottom nepheloid layer is also clearly indicated by the lower $\delta^{13} \mathrm{C}_{\mathrm{OC}}$ values in the bottom SPM (Fig. 8b). IPLderived brGDGTs in marine SPM show a completely different pattern (Fig. 8e) and do not seem to be transported from the Tagus River into the ocean.

A further clue towards potential sources of brGDGTs in the marine system can be obtained by comparing their distributions. Figure 4 shows that marine SPM is on average less dominated by brGDGT IIa than river SPM. Furthermore, the MBT' and DC values of brGDGTs in marine SPM varied more than those of Tagus River SPM (Fig. 10a). The spatial distribution of CL MBT' (Fig. 9c) and DC values (Fig. 9e) showed lower MBT' and higher DC values in the deeper water layers than in surface waters. This trend was also apparent in the MBT' and DC values of IPL-derived brGDGTs (Figs. 9b and 9d), although it was not possible to obtain as much data. The input of brGDGTs in river SPM is still clear from these plots since MBT' and DC values of the coastal stations $(\mathrm{A}-\mathrm{C})$ are comparable to those in river SPM. Further away from the river estuary, brGDGTs in marine SPM do not only show a substantially lower concentration, but the changing DC and MBT' values also reveal a different distribution (Fig. 9c-f). This can only be explained by a rapid dilution of the river SPM with in situ production of brGDGTs in the marine water column (albeit at much lower levels than in the river). This is consistent with expected alterations in brGDGTs since the higher $\mathrm{pH}$ of sea water and lower temperatures in deeper waters would give rise to the observed spatial patterns (i.e., higher DC and lower MBT' values).

The brGDGT composition of marine surface sediments, in contrast to that of marine SPM, may provide a signature that is averaged over seasons and years. However, it may be affected by in situ production in the sediment (cf. Peterse et al., 2009). As was seen for marine SPM (Fig. 8c), the CL brGDGT concentrations normalized per gOC in the marine sediments were highest at the station (A) closest to the estuary, with a markedly declining trend with further distance from the river estuary (Fig. 8i). Surprisingly, the CL brGDGT concentration at station A was even higher than that in the Tagus River SPM (Fig. 8g). This might be caused by faster degradation of other riverine organic matter, while CL brGDGTs were more stable and consequently slightly increased in concentration (normalized to OC) (cf. Huguet et al., 2008). Overall, the concentration trend is in line with rapid dilution of brGDGTs delivered from the river to the ocean.

The next step is to consider the brGDGT distribution of the marine sediments. The MBT' of CL brGDGTs was slightly higher than that of the Tagus River SPM (Fig. 10a) and showed no spatial variation (Fig. 9h). The DC in the coastal station A was similar to that of river SPM (Fig. 10a), but it showed a clear increase from the coast to the ocean (Fig. 9i), consistent with the trend in marine SPM (Fig. 9e). IPLderived brGDGT had a constant MBT', but it was higher than that of CL GDGTs. The DC of IPL-derived brGDGTs in marine sediment showed a similar increase with increasing 
distance offshore as for CL brGDGTs, although the trend was more scattered (Fig. 9i). Overall, these observed distributional changes are in line with an increasingly important contribution of marine in situ production of brGDGTs with increasing distance from the river estuary.

If the MBT' and DC would in general change in the same way from river to ocean, it would help make predictions on how the MBT'/CBT proxy in marine sediments should be interpreted. Similar studies have been carried out in other locations. An increase of the DC from soil to the marine environment has been described so far in all studied locations (Yangtze River, Zhu et al., 2011; Pearl River, Zhang et al., 2012; a Norwegian fjord, Peterse et al., 2009; and the Amazon River, Zell et al., 2014). This increase of the DC was assumed to be due to in situ production of brGDGTs in the marine environment, since the $\mathrm{pH}$ in the marine environment $(\mathrm{pH} \approx 8)$ is usually higher compared to that of soils and river water. In contrast, changes in MBT' in transects from land to ocean are different in different locations. On the Portuguese coast and on the East China Sea shelf (Zhu et al., 2011), the MBT' increased, but it remained unchanged on the South China Sea shelf (Zhang et al., 2012) and for the Amazon shelf it strongly decreased in both the CL and IPLderived fraction (Zell et al., 2014). This might be dependent on the marine water temperature compared to the continental air temperature. Further research is needed to understand the influences on the distribution of brGDGTs that were produced in the marine environment.

\subsection{Implications for the use of GDGT-based proxies in marine sediments}

\subsubsection{BIT index}

The BIT index was originally used to trace terrestrial OC input from land to ocean (Hopmans et al., 2004). Subsequently, since brGDGTs occur ubiquitously in soils (Weijers et al., 2006b) and because brGDGTs are not associated with fresh higher plant debris (Walsh et al., 2008), it is interpreted as a tracer of soil OC (e.g., Huguet et al., 2007; Weijers et al., 2009). In the case of the Tagus River basin, we found that the brGDGTs in the river are not only derived from soils but also produced in situ, in line with other recent studies of river systems (Zell et al., 2013a, b; De Jonge et al., 2014). Therefore, the BIT index should be considered as an indicator for continental OC rather than for soil OC. In the marine environment, the BIT decreases strongly with increasing distance from the river mouth. This can be seen clearly in both SPM and marine surface sediments (Fig. 9a, g). This trend in BIT from high values in the terrestrial environment to low values in the marine environment is still in agreement with the first observation for the Congo River system (Hopmans et al., 2004). However, follow-up studies have suggested that changes in BIT in marine systems are predominantly due to changes in the crenarchaeol concentration (Castañeda et al.,
2010; Schmidt et al., 2010; Fietz et al., 2011; Smith et al., 2012). Our data also show high crenarchaeol concentrations close to the shore (Fig. 8d, j), but they also reveal that by far the highest brGDGT concentrations are found close to the river estuary. This indicates that, at least for the Tagus River system, brGDGT concentrations are also important in determining the BIT index and that, in fact, the declining brGDGT concentrations with increasing distance from the river estuary are the key factor in the declining BIT values. Therefore, despite the mixed origin of the brGDGTs in the river (i.e., soil-derived and aquatic), the BIT in the Tagus River system works as a tracer for continental OC. Nevertheless, in future studies it remains recommendable to survey the concentrations of brGDGTs and crenarchaeol in addition to determining the BIT index.

\subsubsection{Implications for the MBT'/CBT proxy}

The MBT'/CBT proxy has been used to reconstruct MAAT and soil $\mathrm{pH}$ of the river basin by determining brGDGT distributions in marine sediments deposited in the vicinity of a river outflow (e.g., Weijers et al., 2007b). Subsequently, various problems with this approach have been reported, i.e., the potentially increased input of brGDGTs from a region that is not representative for the whole basin, for example from colder mountain regions (Bendle et al., 2010), production of brGDGTs in the river (Zell et al., 2013a, b; De Jonge et al., 2014), and production of brGDGTs in the marine environment (Peterse et al., 2009; Zell et al., 2014). Here, we followed in detail the transport of brGDGTs in the Tagus River system from source to sink and are able to evaluate potential difficulties with this approach.

In the case of the Tagus River basin, we encountered various problems. First, the MAAT cannot be accurately reconstructed using the brGDGT distribution of the soils. Reconstructed temperatures using a global soil calibration (Peterse et al., 2012) are between 0 and $10^{\circ} \mathrm{C}$, while the actual MAAT of the soil sampling sites is substantially higher, i.e., between 10 and $17^{\circ} \mathrm{C}$ (Table 1). As discussed previously, caution has to be taken when the MBT'/CBT is used for MAAT reconstructions in dry environments (Peterse et al., 2012; Dirghani et al, 2013; Menge et al. 2013) and, clearly, this applies to the Tagus River basin. Second, due to the much higher concentrations of brGDGTs in the Tagus River SPM compared to the soils and their different brGDGT distributions, it is likely that the brGDGTs in the Tagus River are predominantly produced in the river. This means that the brGDGTs in the river do not represent the brGDGT distribution of the soils, which makes it impossible to reconstruct river basin soil conditions using brGDGTs transported by the Tagus River. Third, from the river estuary to the open marine environment, brGDGT distributions (and consequently MBT' and CBT values) changed again due to the increasing influence of in situ produced marine brGDGTs. This shows that at least for the Tagus River system, but probably more 
generally, brGDGTs in marine sediments cannot directly be used to reconstruct soil $\mathrm{pH}$ and MAAT of the river basin.

Since the majority of the brGDGTs in the SPM of the Tagus River are likely produced in the river, it might be possible to reconstruct the environmental conditions in the river instead of those of the river basin soils. It is well known that brGDGT soil calibrations differ from those reported for aquatic environments (Tierney et al., 2010; Zink et al., 2010; Pearson et al., 2011; Sun et al., 2011; Loomis et al., 2012). However, calibrations for river water have not yet been reported. Therefore, for the reconstruction of the river $\mathrm{pH}$ and temperature, the application of a lake calibration is currently used (cf. De Jonge et al., 2014). A number of calibrations have been reported for the MBT/CBT, but so far no lake calibrations for the MBT'/CBT exist to the best of our knowledge. Furthermore, river water temperatures were not measured when river SPM was collected, and we were not successful in obtaining Tagus River temperature data from the existing database either. Therefore, we are for the moment unable to test if climate reconstructions using Tagus Riverderived brGDGTs should, in principle, be possible.

In order to prevent the strong influence of marine in situ produced brGDGTs, it is recommendable to use cores that were taken close to the river mouth. How far away from the river the river-originating brGDGTs are still dominant over the ones produced in the marine environment can be influenced by several factors, for example the degradation processes in the estuary, sedimentation rates, and the ocean currents. The BIT index might be a good indicator for high river influence. In general, the higher the BIT the more likely it is that there is more river input and thus a more similar MBT' and DC to that of the river SPM. From our data, we can see that at a BIT $<0.05$, the DC was in particular quite different. Therefore, we certainly recommend not to apply the MBT'/CBT in sediment records with a BIT $<0.05$. Further studies are needed to understand what influences the MBT' and DC in brGDGTs that are produced in the marine environment. In general, this study shows that there are many factors that can complicate the use of the MBT'/CBT for reconstructing river basin temperatures and soil $\mathrm{pH}$ from marine sediment cores. Therefore, it is absolutely necessary to investigate the basin soils, river SPM, and marine surface sediments before interpreting the MBT'/CBT records from a marine sediment core. This severely complicates paleoenvironmental studies going back further in time.

\section{Conclusions}

Our study shows that in the case of the Tagus River system, there are several problems concerning the use of the MBT'/CBT to reconstruct river basin MAAT and soil $\mathrm{pH}$. First, soil brGDGTs in dry environments do not accurately predict the MAAT and soil $\mathrm{pH}$. Second, brGDGTs in the river SPM are mainly produced in situ. Third, MBT' and DC val- ues in marine sediments are further influenced by brGDGTs produced in the marine environment. Since the majority of brGDGTs seem to be produced in the aquatic environment, it is probably possible to use a lake (or river) calibration to reconstruct the environmental conditions of the river itself. This indicates that in order to decide whether the MBT'/CBT can be used to reconstruct the terrestrial paleoenvironmental changes from marine sediment cores, it is essential to test the MBT'/CBT of drainage basin soils and river SPM. If it is decided that the MBT'/CBT can be used for environmental reconstructions, the core should be taken as close to the river mouth as possible to minimize the influence of brGDGTs produced in the marine environment.

Acknowledgements. The research leading to these results was funded by the European Research Council (ERC) under the European Union's Seventh Framework Program (FP7/2007-2013) ERC grant agreement [226600]. We thank Jérôme Bonnin for Tagus soil sampling, Pierre-Antoine Dessandier for the elemental analysis, and Henko de Stigter and Silvia Nave for help with the cruise preparation. We also thank the captain and crew of the R/V Pelagia for their excellent services during the PACEMAKER cruise.

Edited by: L. Cotrim da Cunha

\section{References}

Alt-Epping, U., Mil-Homens, M., Hebbeln, D., Abrantes, F., and Schneider, R. R.: Provenance of organic matter and nutrient conditions on a river- and upwelling influenced shelf: A case study from the Portuguese Margin, Mar. Geol., 243, 169-179, 2007.

Ambar, I., Fiúza, A. F. G.: Some features of the Portugal current system: a poleward slope undercurrent, an upwellingrelated summer southward flow and an autumn-winter poleward coastal surface current, in: Proceedings of the second international conference on air-sea interaction and on meteorology and oceanography of the coastal zone, edited by: Katsaros, K. B., Fiúza, A. F. G., and Ambar, I., Boston, USA, Am. Meteorol. Soc., 286-287, 1994.

Atlas Nacional de España. Seccion 11 (Climatologia, Geologia y Relieve, Hydrologia), Instituto Geografico Nacional, Ministerio de Obras Publicas y Transportes, Madrid, 1993.

Ballantyne, A. P., Greenwood, D. R., Sinninghe Damsté, J. S., Csank, A. Z., Eberle, J. J., and Rybczynski, N.: Significantly warmer Arctic surface temperatures during the Pliocene indicated by multiple independent proxies, Geology, 38, 603-606, doi:10.1130/G30815.1, 2010.

Bendle, J. A., Weijers, J. W. H., Maslin, M. A., Sinninghe Damsté, J. S., Schouten, S., Hopmans, E. C., Boot, C. S., and Pancost, R. D.: Major changes in glacial and Holocene terrestrial temperatures and sources of organic carbon recorded in the Amazon fan by tetraether lipids, Geochem. Geophys. Geosyst., 11, 14, doi:10.1029/2010GC003308, 2010.

Castañeda, I. S., Schefuß, E., Pätzold, J., Sinninghe Damsté, J. S., Weldeab, S., and Schouten, S.: Millennial-scale sea surface temperature changes in the eastern Mediterranean (Nile River Delta region) over the last 27000 years, Paleoceanography, 25, PA1208, doi:10.1029/2009PA001740, 2010. 
Cleveland, C. C., Wieder, W. R., Reed, S. C., and Townsend, A. R.: Experimental drought in a tropical rain forest increases soil carbon dioxide losses to the atmosphere, Ecology, 91, 2313-2323, 2010.

D’Anjou, R. M., Wei, J. H., Castañeda, I. S., Brigham-Grette, J., Petsch, S. T., and Finkelstein, D. B.: High-latitude environmental change during MIS 9 and 11: Biogeochemical evidence from Lake El'gygytgyn, Far East Russia, Clim. Past, 9, 567-581, doi:10.5194/cp-9-567-2013, 2013.

De Jonge, C., Hopmans, E. C., Stadnitskaia, A., Rijpstra, W. I. C., Hofland, R., Tegelaar, E., and Sinninghe Damsté, J. S.: Identification of novel penta- and hexamethylated branched glycerol dialkyl glycerol tetraethers in peat using HPLC-MS2, GC-MS and GC-SMB-MS, Org. Geochem., 54, 78-82, 2013.

De Jonge, C., Stadnitskaia, A., Hopmans, E. C., Cherkashov, G., Fedotov, and Sinninghe Damsté, J. S.: In-situ produced branched glycerol dialkyl glycerol tetraethers in suspended particulate matter from the Yenisei River, Eastern Siberia, Geochim. Cosmochim. Acta, 125, 476-491, 2014.

Dirghangi, S. S., Pagani, M., Hren, M. T., and Tipple, B. J.: Distribution of glycerol dialkyl glycerol tetraethers in soils from two environmental transects in the USA, Org. Geochem., 59, 49-60, 2013.

Donders, T. H., Weijers, J. W. H., Munsterman, D. K., Kloosterboervan Hoeve, M. L., Buckles, L. K., Pancost, R. D., Schouten, S., Sinninghe Damsté, J. S., and Brinkhuis, H.: Strong climate coupling of terrestrial and marine environments in the Miocene of northwest Europe, Earth Planet. Sci. Lett. 281, 215-225, 2009.

Fawcett, P. J., Werne, J. P., Anderson, R. S., Heikoop, J. M., Brown, E. T., Berke, M. A., Smith, S. J., Goff, F., Donohoo-Hurley, L., Cisneros-Dozal, L. M., Schouten, S., Sinninghe Damsté, J. S., Huang, Y., Toney, J., Fessenden, J., WoldeGabriel, G., Atudorei, V., Geissman, J. W., and Allen, C. D.: Extended megadroughts in the southwestern United States during Pleistocene interglacials, Nature, 470, 518-521, doi:10.1038/nature09839, 2011.

Fietz, S., Martínez-Garcia, A., Huguet, C., Rueda, G., and RosellMelé, A.: Constraints in the application of the Branched and Isoprenoid Tetraether index as a terrestrial input proxy, J. Geophys. Res., 116, C10, doi:10.1029/2011JC007062, 2011.

Fiúza, A. F. G., Macedo, M. E., and Guerreiro, M. R.: Climatological space and time variation of the Portuguese Coastal Upwelling, Oceanol. Acta, 5, 31-40, 1982.

Fry, B. and Sherr E. B.: $\mathrm{d}^{13} \mathrm{C}$ measurements as indicators of carbon flow in marine and freshwater ecosystems, Contrib. Mar. Sci., 27, 13-47, 1984.

Herfort, L., Schouten, S., Boon, J. P., Woltering, M., Baas, M., Weiers, J. W. H., and Sinninghe Damsté, J. S.: Characterization of transport and deposition of terrestrial organic matter in the southern North Sea using the BIT index, Limnol. Ocean. 51, 2196-2205, 2006.

Hopmans, E. C., Weijers, J. W. H., Schefuß, E., Herfort, L., Sinninghe Damsté, J. S., and Schouten, S.: A novel proxy for terrestrial organic matter in sediments based on branched and isoprenoid tetraether lipids, Earth Planet. Sci. Lett., 224, 107-116, 2004.

Hu, J., Meyers, P. A., Chen, G., Peng, P., and Yang, Q.: Archaeal and bacterial glycerol dialkyl glycerol tetraethers in sediments from the Eastern Lau Spreading Center, South Pacific Ocean, Org. Geochem., 43, 162-167, 2012.
Huguet, C., Hopmans, E. C., Febo-Ayala, W., Thompson, D. H., Sinninghe Damsté, J. S., and Schouten, S.: An improved method to determine the absolute abundance of glycerol dibiphytanyl glycerol tetraether lipids, Org. Geochem., 37, 1036-1041, 2006.

Huguet, C., Smittenberg, R.H., Boer, W., Sinninghe Damsté, J. S., and Schouten, S.: Twentieth century proxy records of temperature and soil organic matter input in the Drammensfjord, southern Norway, Org. Geochem, 38, 1838-1849, 2007.

Huguet, C., de Lange, G. J., Gustafsson, Ö., Middelburg, J. J., Sinninghe Damsté, J. S., and Schouten, S.: Selective preservation of soil organic matter in oxidized marine sediments (Madeira Abyssal Plain), Geochim. Cosmochim. Acta, 72, 6061-6068, 2008.

Huguet, C., Kim, J.-H., de Lange, G. J., Sinninghe Damsté, J. S., and Schouten, S.: Effects of long term oxic degradation on the , TEX $_{86}$ and BIT organic proxies, Org. Geochem., 40, 1188-1194, 2009.

Jia, G., Rao, Z., Zhang, J., Li, Z., and Chen, F.: Tetraether biomarker records from a loess-paleosol sequence in the western Chinese Loess Plateau, Front. Microbiol., 4, 199, doi:10.3389/fmicb.2013.00199, 2013.

Jobbágy, E. G. and Jackson, R. B.: The vertical distribution of soil organic carbon and its relation to climate and vegetation, Ecol. Appl. 10, 423-436, 2000.

Jouanneau, J. M., Garcia, C., Oliveira, A., Rodrigues, A., Dias, J. A., and Weber, O.: Dispersal and deposition of suspended sediment on the shelf off the Tagus and Sado estuaries, S. W. Portugal. Prog. Ocean, 42, 233-257, 1998.

Kim, J.-H., Zarzycka, B., Buscail, R., Peterse, F., Bonnin, J., Ludwig, W., Schouten, S., and Sinninghe Damsté, J. S.: Contribution of river-borne soil organic carbon to the Gulf of Lions (NW Mediterranean), Limnol. Oceanogr. 55, 507-518, 2010.

Loomis, S.E., Russell James, M., Ladd, B., Street-Perrott, A., and Sinninghe Damsté, J. S.: Calibration and application of the branched GDGT temperature proxy on East African lake sediments, Earth Planet. Sci. Lett., 42, 357-358, 2012.

Lorrain, A., Savoye, N., Chauvaud, L., Paulet, Y.-M., and Naulet, N.: Decarbonation and preservation method for the analysis of organic $\mathrm{C}$ and $\mathrm{N}$ contents and stable isotope ratios of lowcarbonated suspended particulate material, Anal. Chim. Acta, 491, 125-133, 2003.

Loureiro, J. M., and Macedo, M. E.: Bacia hidrografica do rio Tejo. In Monografias hidrologicas dos principais cursops de agua de Portugal continental. Direccao Geral dos Recursos e Aproveitamentos Hidraulicos, 281-337, 1986.

Martins, C. S., Hamann, M., and Fuiza, A. F. G.: Surface circulation in the eastern North Atlantic from drifters and altimetry, J. Geophys. Res., 107, 3217, doi:10.1029/2000JC000345, 2002.

Menges, J., Huguet, C., Alcañiz, J. M., Fietz, S., Sachse, D., and Rosell-Melé, A.: Water availability determines branched glycerol dialkyl glycerol tetraether distributions in soils of the Iberian Peninsula, Biogeosciences, 11, 2571-2581, doi:10.5194/bg-112571-2014, 2014.

Mougenot, D.: Géologie de la Marge Portugaise, Thèse de Doctorat d'Etat és Sciences Naturelles, Univ. Pierre et Marie Curie, Paris VI, 1988.

Niemann, H., Stadnitskaia, A., Wirth, S. B., Gilli, A., Anselmetti, F. S., Sinninghe Damsté, J. S., Schouten, S., Hopmans, E. C., and Lehmann, M. F.: Bacterial GDGTs in Holocene sediments 
and catchment soils of a high Alpine lake: application of the MBT / CBT-paleothermometer, Clim. Past, 8, 889-906, 2012, http://www.clim-past.net/8/889/2012/.

Ninyerola, M., Pons, X., and Roure, J.: Atlas Climático Digital de la Península Ibérica. Metodología y aplicaciones en bioclimatología y geobotánica. ISBN 932860-8-7, Universidad Autónoma de Barcelona, Bellaterra, 2005.

Oppermann, B. I., Michaelis, W., Blumenberg, M., Frerichs, J., Schulz, H. M., Schippers, A., Beaubien, S. E., and Krüger, M.: Soil microbial community changes as a result of long-term exposure to a natural $\mathrm{CO}_{2}$ vent, Geochim. Cosmochim. Acta 74, 2697-2716, 2010.

Paiva, P., Jouanneau, J.-M., Araújo, F., Weber, O., Rodrigues, A., and Dias, J. M. A.: Elemental distribution in a sedimentary deposit on the shelf off the Tagus estuary (Portugal), Water. Air. Soil Pollut., 99, 507-514, 1997.

Pancost, R. D. and Sinninghe Damsté, J. S.: Carbon isotopic compositions of prokaryotic lipids as tracers of carbon cycling in diverse settings, Chem. Geol. 195, 29-58, 2003.

Pearson, E. J., Juggins, S., Talbot, H. M., Weckström, J., Rosén, P., Ryves, D. B., Roberts, S. J., and Schmidt, R.: A lacustrine GDGT-temperature calibration from the Scandinavian Arctic to Antarctic: Renewed potential for the application of GDGTpaleothermometry in lakes, Geochim. Cosmochim. Acta, 75, 6225-6238, 2011.

Peterse, F., Kim, J.-H., Schouten, S., Klitgaard Kristensen, D., Koç, N., and Sinninghe Damsté, J. S.: Constraints on the application of the MBT / CBT palaeothermometer at high latitude environments (Svalbard, Norway), Org. Geochem. 40, 692-699, 2009.

Peterse, F., Nicol, G. W., Schouten, S., and Sinninghe Damsté, J. S.: Influence of soil $\mathrm{pH}$ on the abundance and distribution of core and intact polar lipid-derived branched GDGTs in soil, Org. Geochem., 41, 1171-1175, doi:10.1016/j.orggeochem.2010.07.004, 2010.

Peterse, F., Prins, M. A., Beets, C. J., Troelstra, S. R., Zheng, H., Gu, Z., Schouten, S., and Sinninghe Damsté, J. S.: Decoupled warming and monsoon precipitation in East Asia over the last deglaciation, Earth Planet. Sci. Lett., 301, 256-264, 2011 a.

Peterse, F., Hopmans, E. C., Schouten, S., Mets, A., Rijpstra, W. I. C., and Sinninghe Damsté, J. S.: Identification and distribution of intact polar branched tetraether lipids in peat and soil, Org. Geochem. 42, 1007-1015, 2011 b.

Peterse, F., van der Meer, J., Schouten, S., Weijers, J. W. H., Fierer, N., Jackson, R. B., Kim, J.-H., and Sinninghe Damsté, J. S.: Revised calibration of the MBT-CBT paleotemperature proxy based on branched tetraether membrane lipids in surface soils. Geochim, Cosmochim. Acta, 96, 215-229, 2012.

Pitcher, A., Hopmans, E. C., Schouten, S., and Sinninghe Damsté, J. S.: Separation of core and intact polar archaeal tetraether lipids using silica columns: Insights into living and fossil biomass contributions, Org. Geochem. 40, 12-19, 2009.

Rueda, G., Rosell-Melé, A., Escala, M., Gyllencreutz, R., and Backman, J.: Comparison of instrumental and GDGT-based estimates of sea surface and air temperatures from the Skagerrak, Org. Geochem., 40, 287-291, 2009.

Schmidt, F., Hinrichs, K.-U. and Elvert, M.: Sources, transport, and partitioning of organic matter at a highly dynamic continental margin, Mar. Chem., 118, 37-55, 2010.
Schouten, S., Huguet, C., Hopmans, E. C., Kienhuis, M. V. M., and Sinninghe Damsté, J. S.: Analytical methodology for TEX86 paleothermometry by high-performance liquid chromatography/atmospheric pressure chemical ionization-mass spectrometry, Anal. Chem., 79, 2940-2944, 2007.

Sinninghe Damsté, J. S., Hopmans, E. C., Pancost, R. D., Schouten, S., and Geenevasen, J. A. J.: Newly discovered non-isoprenoid glycerol dialkyl glycerol tetraether lipids in sediments, Chem. Commun., 1683-1684, 2000.

Sinninghe Damsté, J. S., Ossebaar, J., Abbas, B., Schouten, S., and Verschuren, D.: Fluxes and distribution of tetraether lipids in an equatorial African lake: Constraints on the application of the TEX $_{86}$ palaeothermometer and BIT index in lacustrine settings, Geochim, Cosmochim. Acta, 73, 4232-4249, 2009.

Sinninghe Damsté, J. S., Rijpstra, W. I. C., Hopmans, E. C., Weijers, J. W. H., Foesel, B. U., Overmann, J., and Dedysh, S. N.: 13,16Dimethyl Octacosanedioic Acid (iso-Diabolic Acid), a Common Membrane-Spanning Lipid of Acidobacteria Subdivisions 1 and 3. Appl, Environ. Microbiol. 77, 4147-4154, 2011.

Strong, D. J., Flecker, R., Valdes, P. J., Wilkinson, I. P., Rees, J. G., Zong, Y. Q., Lloyd, J. M., Garrett, E., and Pancost, R. D.: Organic matter distribution in the modern sediments of the Pearl River Estuary, Org. Geochem., 49, 68-82, 2012.

Sun, Q., Chu, G. Q., Liu, M. M., Xie, M. M., Li, S. Q., Ling, Y. A., Wang, X. H., Shi, L. M., Jia, G. D., and Lu, H. Y.: Distributions and temperature dependence of branched glycerol dialkyl glycerol tetraethers in recent lacustrine sediments from China and Nepal, J. Geophys. Res., 116, G1, doi:10.1029/2010JG001365, 2011.

Smith, R. W., Bianchi, T. S., and Li, X.: A re-evaluation of the use of branched GDGTs as terrestrial biomarkers: Implications for the BIT Index, Geochim. Cosmochim. Acta, 80, 14-29, 2012.

Tierney, J. E., Russell, J. M., Eggermont, H., Hopmans, E. C., Verschuren, D., and Sinninghe Damsté, J. S.: Environmental controls on branched tetraether lipid distributions in tropical East African lake sediments, Geochim. Cosmochim. Acta, 74, 49024918, 2010.

Trigo R. M., Añel J., Barriopedro D., Gimeno L., Allen M., Nieto R., Neil Massey N., Castillo R., and García-Herrera R.: The record winter drought of 2011-2012 in the Iberian Peninsula, In 'Explaining extreme weather events of 2012 from a climate perspective', Special supplement of B. Am. Meterol. Soc., 94, 4145, 2013.

Tyler, J. J., Nederbragt, A. J., Jones, V. J., and Thurow, J. W.: Assessing past temperature and soil $\mathrm{pH}$ estimates from bacterial tetraether membrane lipids: Evidence from the recent lake sediments of Lochnagar, Scotland, J. Geophys. Res., 115, G1, doi:10.1029/2009JG001109, 2010.

Vale, C., Ferreira, A., Micaelo, C., Caetano, M., Pereira, E., Madureira, M., and Ramalhosa, E.: Mobility of contaminants inrelation to dredging operations in a mesotidal estuary (Tagus Estuary, Portugal), Water Sci. Technol., 37, 25-31, 1998.

Walsh, E. M., Ingalls, A. E., and Keil, R. G.: Sources and Transport of Terrestrial Organic Matter in Vancouver Island Fjords and the Vancouver-Washington Margin: A Multiproxy Approach Using $\mathrm{d}^{13}$ Corg, Lignin Phenols, and the Ether Lipid BIT Index, Limnol. Oceanogr., 53, 1054-1063, 2008.

Weijers, J. W. H., Schouten, S., Hopmans, E. C., Geenevasen, J. A. J., David, O. R. P., Coleman, J. M., Pancost, R. D., and Sinninghe 
Damsté, J. S.: Membrane lipids of mesophilic anaerobic bacteria thriving in peats have typical archaeal traits, Environ. Microbiol., 8, 648-657, 2006a.

Weijers, J. W. H., Schouten, S., Spaargaren, O. C., and Sinninghe Damsté, J. S.: Occurrence and distribution of tetraether membrane lipids in soils: Implications for the use of the $\mathrm{TEX}_{86}$ proxy and the BIT index, Org. Geochem., 37, 1680-1693, 2006b.

Weijers, J. W. H., Schouten, S., van den Donker, J. C., Hopmans, E. C., and Sinninghe Damsté, J. S.: Environmental controls on bacterial tetraether membrane lipid distribution in soils, Geochim. Cosmochim. Acta, 71, 703-713, 2007a.

Weijers, J. W. H., Schefuß, E., Schouten, S., and Sinninghe Damsté, J. S.: Coupled thermal and hydrological evolution of tropical Africa over the last deglaciation, Science, 315, 1701-1704, 2007b.

Weijers, J. W. H., Schouten, S., Schefuá, E., Schneider, R. R., and Sinninghe Damsté, J. S.: Disentangling marine, soil and plant organic carbon contributions to continental margin sediments: A multi-proxy approach in a 20,000 year sediment record from the Congo deep-sea fan, Geochim. Cosmochim. Acta, 73, 119-132, 2009.

Weijers, J. W. H., Wiesenberg, G. L. B., Bol, R., Hopmans, E. C., and Pancost, R. D.: Carbon isotopic composition of branched tetraether membrane lipids in soils suggest a rapid turnover and a heterotrophic life style of their source organism(s), Biogeosciences, 7, 2959-2973, doi:10.5194/bg-7-2959-2010, 2010.

Weijers, J. W. H., Bernhardt, B., Peterse, F., Werne, J. P., Dungait, J. A. J., Schouten, S., and Sinninghe Damsté, J. S.: Absence of seasonal patterns in MBT-CBT indices in mid-latitude soils, Geochim. Cosmochim. Acta, 75, 3179-3190, 2011.

Williams, M., Shimabukuro, Y. E., Herbert, D. A., Pardi Lacruz, S., Renno, C., and Rastetter, E. B.: Heterogeneity of Soils and Vegetation in an Eastern Amazonian Rain Forest: Implications for Scaling Up Biomass and Production, Ecosystems, 5, 692$704,2002$.

Wu, W., Zhao, L., Pei, Y., Ding, W., Yang, H., and Xu, Y.: Variability of tetraether lipids in Yellow River-dominated continental margin during the past eight decades: Implications for organic matter sources and river channel shifts, Org. Geochem., 60, 33$39,2013$.
Xie, S., Pancost, R. D., Chen, L., Evershed, R. P., Yang, H., Zhang, K., Huang, J., and Xu, Y.: Microbial lipid records of highly alkaline deposits and enhanced aridity associated with significant uplift of the Tibetan Plateau in the Late Miocene, Geology, 40, 291-294, 2012.

Yang, G., Zhang, C. L., Xie, S., Chen, Z., Gao, M., Ge, Z., and Yang, Z.: Microbial glycerol dialkyl glycerol tetraethers from river water and soil near the Three Gorges Dam on the Yangtze River, Org. Geochem., 56, 40-50, 2013.

Yang, H., Ding, W., Wang, J., Jin, C., He, G., Qin, Y., and Xie, S.: Soil $\mathrm{pH}$ impact on microbial tetraether lipids and terrestrial input index (BIT) in China, Sci. China Earth Sci., 55, 236-245, 2011.

Zech, R., Gao,L., Tarozo, R., and Huang, Y.: Branched glycerol dialkyl glycerol tetraethers in Pleistocene loess-paleosol sequences: three case studies, Org. Geochem., 53, 38-44, 2012.

Zell, C., Kim, J.-H., Abril, G., Sobrinho, R. L., Dorhout, D., Moreira-Turcq, P., and Sinninghe Damsté, J. S.: Impact of seasonal hydrological variation on the distributions of tetraether lipids along the Amazon River in the central Amazon basin: implications for the MBT / CBT paleothermometer and the BIT index, Front. Microbiol., 4, 228, doi:10.3389/fmicb.2013.00228, 2013a.

Zell, C., Kim, J.-H., Moreira-Turcq, P., Abril, G., Hopmans, E. C., Bonnet, M.-P., Lima Sobrinho, R., and Sinninghe Damsté, J. S.: Disentangling the origins of branched tetraether lipids and crenarchaeol in the lower Amazon River: Implications for GDGTbased proxies, Limnol. Ocean., 58, 343-353, 2013 b.

Zhang, C.L., Wang, J., Wei, Y., Zhu, C., Huang, L., and Dong, H.: Production of branched tetraether lipids in the lower pearl river and estuary: effects of extraction methods and impact on bGDGT proxies, Front. Microbiol., 2, 274, doi:10.3389/fmicb.2011.00274, 2012.

Zhu, C., Weijers, J. W. H., Wagner, T., Pan, J. M., Chen, J. F., and Pancost, R. D.: Sources and distributions of tetraether lipids in surface sediments across a large river-dominated continental margin, Org. Geochem., 42, 376-386, 2011.

Zink, K.-G., Vandergoes, M. J., Mangelsdorf, K., DieffenbacherKrall, A. C., and Schwark, L.: Application of bacterial glycerol dialkyl glycerol tetraethers (GDGTs) to develop modern and past temperature estimates from New Zealand lakes, Org. Geochem., 41, 1060-1066, 2010. 